\title{
Middle Jurassic Tethyan-Boreal ostracod faunal links: a case study from the Callovian of Portugal
}

\author{
Vanessa Pais ${ }^{1}$, Maria Cristina Cabral ${ }^{2 *}$, Alan Lord ${ }^{3}$, Ana Cristina Azerêdo ${ }^{2}$ \& \\ Liam Gallagher ${ }^{4}$ \\ ${ }^{1}$ Departamento de Geologia, Faculdade de Ciências, Universidade de Lisboa, Campo Grande, C6, $4^{\circ}$ piso, \\ 1749-016 Lisboa, Portugal \\ ${ }^{2}$ Departamento de Geologia and Instituto Dom Luiz (IDL), Faculdade de Ciências, Universidade de Lisboa, Campo Grande, \\ C6, $4^{\circ}$ piso, 1749-016 Lisboa, Portugal \\ ${ }^{3}$ Senckenberg Forschungsinstitut, Senckenberganlage 25, D-60325 Frankfurt-am-Main, Germany \\ ${ }^{4}$ Network Stratigraphic Consulting Ltd, Harvest House, Cranborne Road, Potters Bar, Hertfordshire EN6 3JF, UK \\ *Correspondence: mccabral@fc.ul.pt
}

\begin{abstract}
Late Callovian (athleta Chronozone) age sediments of Pedrógão, west coast Portugal, yielded a low diversity ostracod assemblage with relatively little in common with coeval NW European assemblages except at the weak level of comparative (cf.) species identification. Five new marine species are described (Neurocythere multiforma sp. nov., Palaeocytheridea (Malzevia)? dorsocostata sp. nov., Praebythoceratina parascrobiculata sp. nov., Praeschuleridea lisensis sp. nov., Virgulacytheridea posteroacuminata sp. nov.) and three previously described non-marine species recorded that so far are indigenous to Portugal (Septacandona azeredae, Sinuocythere pedrogaensis, Theriosynoecum helmdachi). Ostracod taxonomic links to western Tethys are evident but weak. Calcareous nannofossil assemblages were analysed for biostratigraphical control.
\end{abstract}

Keywords: Callovian, Lusitanian Basin, ostracod taxonomy, calcareous nannofossil biostratigraphy, palaeobiogeography

Supplementary material: Sample data and raw ostracod counts are available at https://doi.org/10.6084/m9.figshare.c. 3271394.v1

Received 4 November 2015; revised 10 March 2016; accepted 29 March 2016

Our aim in studying the poorly known ostracods from the Callovian sequence at Pedrógão in western Portugal was to elucidate faunal links between the Tethys Ocean to the east and the epicontinental seas of western and northern Europe. In doing so we anticipated finding at least some NW European species from the classic literature of the 1950-70s. The results discussed below show weak palaeobiogeographical links with Tethys but also reveal forms with subtle morphological and therefore taxonomic differences from known Callovian taxa from France, Germany and Britain.

Callovian ostracods from Portugal are poorly known, not least because available sections are limited. Carapito (1998) analysed benthic foraminifers from the Callovian-Oxfordian transition from nearby Cabo Mondego (Farol section) and listed six ostracod species from the athleta ammonite Chronozone, Upper Callovian, but without illustrations the record has limited use. It is possible that Carapito's ostracod species Micropneumatocythere sp., Lophocythere gr. cruciata and Eoschuleridea sp. correspond to some identified species in the present work. Carapito Krausshar (2008) also recorded Micropneumatocythere? and Eoschuleridea? in the Oxfordian of Cabo Mondego (Praia section). Azerêdo et al. (2002a) similarly listed, but did not figure, marine Callovian ostracods from Pedrógão.

\section{The Lusitanian Basin}

The Lusitanian Basin of west-central Portugal is a north-south elongated basin (Fig. 1) whose genesis is linked with the opening of the North Atlantic Ocean, as with several other Mesozoic peri-Tethyan basins (e.g. Wilson et al. 1989). The basin is infilled by $c .5000 \mathrm{~m}$ of sediments ranging in age from the Late Triassic to
Late Cretaceous, but mostly from the Jurassic. The Upper TriassicMiddle Jurassic succession corresponds to the first major cycle of basin development (Wilson et al. 1989; Azerêdo et al. 2014). During the Middle Jurassic carbonate sediments formed on a west/ NW-dipping ramp system, therefore inner-marine facies dominate in the east/SE and more open-marine facies developed towards the west/NW, namely towards present-day shoreline and offshore (e.g. Azerêdo et al. 2003). A basinwide disconformity separates the Middle Jurassic from the Upper Jurassic, with a hiatus spanning from the Late Callovian to the Early Oxfordian time interval in the west, whereas to the east it may range from the late Bathonian (Ruget-Perrot 1961; Ramalho 1971; Mouterde et al. 1979; Wilson et al. 1989; Azerêdo et al. 2002b). The uppermost Middle Jurassic to lower Upper Jurassic sediments are associated with marked environmental changes over the basin, where depositional settings rapidly evolved from open-marine to shallow-marine, transitional and even to non-marine. This interval is interpreted as reflecting a major forced regressive episode (Azerêdo et al. 2002b), with reflooding leading to a complex pattern of depositional conditions throughout the basin, from freshwater and brackish-lagoonal to marginal- and shallow-marine settings.

In the west part of the basin, one of the most representative sections crops out on the coast at Pedrógão beach, where the Middle Jurassic below the disconformity is of Late Callovian age according to ammonite data (Ruget-Perrot 1961). The biostratigraphy of this Callovian section has been studied chiefly for macrofossils, namely ammonites and brachiopods (Ruget-Perrot 1961; Alméras et al. 1991). Other works covering only the topmost Callovian levels addressed ostracods (Cabral et al. 1998), palynology (Barrón et al. 


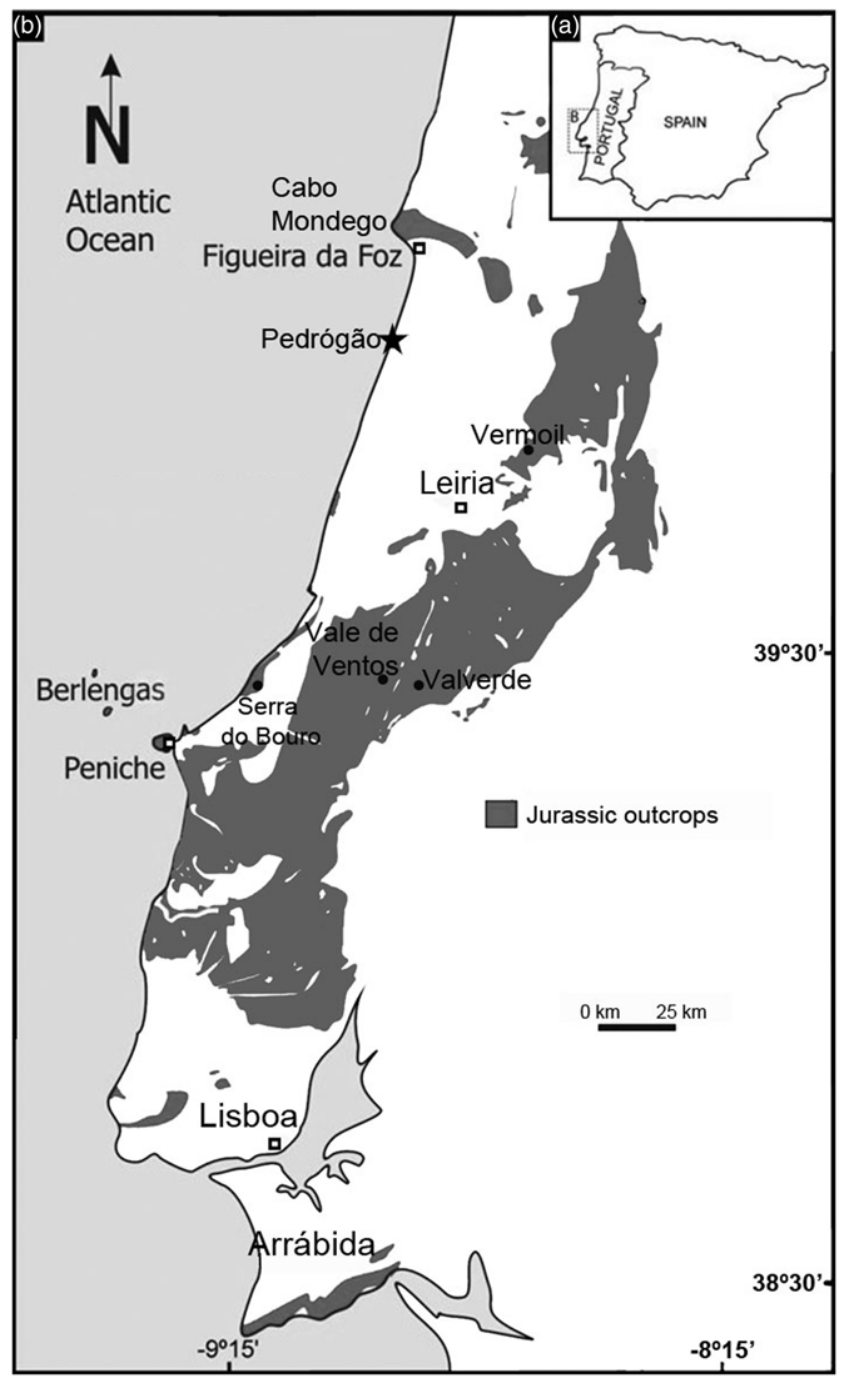

Fig. 1. Jurassic outcrop areas of the onshore Lusitanian Basin with localities mentioned in the text.

1999; Barrón \& Azerêdo 2003) and palynofacies (Silva et al. 2014). The present study focuses in detail on the ostracod assemblages from the Pedrógão Callovian succession using samples from a larger number of beds than previously accessible (because of beach sand cover), as a result of exceptional outcrop exposure in autumn 2014 following coupled storms and high tides.

Note: ammonite chronozones used here are standard NW European zones (see Ogg \& Hinnov in Gradstein et al. 2012) and are referred to simply as 'zones'.

\section{The Pedrógão section}

The study presented here focuses on the section at Pedrógão beach, $30 \mathrm{~km}$ to the south of Cabo Mondego (Fig. 1). The lower part of the section shows marine fossiliferous marls and limestones belonging to the informal Cabo Mondego formation sensu Azerêdo et al. (2003), overlain by a highly variable succession of marls, lignitic marls, bioclastic limestones, fenestral limestones, microbialites, pedogenic- and evaporite-influenced deposits, common desiccation surfaces, and dominantly non-marine fossils, interbedded with levels of restricted marine fossil content (Cabaços Formation; e.g. Ruget-Perrot 1961; Ramalho 1971, 1981; Leinfelder et al. 1988; Azerêdo et al. 2002a, b).

The lower marl-limestone succession is dated by ammonites and brachiopods as Late Callovian (Ruget-Perrot 1961; Mouterde et al.
1979; Alméras et al. 1991), the athleta Zone (the uppermost Callovian lamberti Zone is not recognized over the whole of the basin). Collating the information in Ruget-Perrot (1961), GrambastFessard \& Ramalho (1985), Alméras et al. (1991) and M. Ramalho (unpublished data), our samples up to level $\mathrm{P}(7)$ are clearly Callovian in age (Fig. 2).

The lack of good biostratigraphic biomarkers hampers a precise age assignment of the overlying Cabaços Formation, though overall available data strongly suggest an Oxfordian age. The lowermost deposits of the Cabaços Formation have no age-diagnostic fossils; towards the intermediate part of the unit there is a consistent occurrence over the whole of the basin of the dasycladacean Heteroporella lusitanica (Ramalho 1970) which, coupled with other regional data, suggests a middle Oxfordian age for these levels (cf. Ruget-Perrot 1961; Ramalho 1971, 1981; Leinfelder et al. 1988; Azerêdo et al. 2002a, b).

The lower part of the Pedrógão succession (Fig. 2) is marl dominated, with marl levels much thicker (average 1.5-2 m) than limestone levels (average $0.10-0.25 \mathrm{~m}$ ). Besides ammonites, it is rich in brachiopods, diverse bivalves (including in thin section thinshelled marine bivalve fragments, well known in Jurassic microfacies as 'filaments'), echinoids, marine ostracods and hyaline-walled foraminifers. Towards the top, marl intervals become gradually thinner and limestones thicker, locally exhibiting irregular, ferruginous top surfaces, as at bed $\mathrm{P}(7)$; solitary corals, oysters, brachiopods, rare agglutinate-walled foraminifera and bioturbation occur throughout. This interval is overlain by interbedded marls, lignitic marls and bioclastic limestones, with bivalves, non-marine ostracods and charophyte gyrogonites, $\mathrm{P}(8 \mathrm{~B})-\mathrm{P}(12)$, capped by a $0.5 \mathrm{~m}$ thick couplet $(\mathrm{P}(13 \mathrm{~B})$ and $\mathrm{P}(13 \mathrm{~T}))$ of reddish ferruginous bioclastic limestone layers separated by a highly irregular ferruginized surface, totally draped/infilled by charophyte stems (mostly) and gyrogonites. In the absence of biostratigraphical markers above $\mathrm{P}(7)$, the prominent $\mathrm{P}(13)$ irregular bed and surface were considered by Azerêdo et al. $(2002 a, b)$ to represent the physical boundary between the Middle and the Upper Jurassic at Pedrógão, simply as a sedimentary criterion. However, Azerêdo et al. (2002b) recognized that the marked facies change is clearly recorded earlier, marking it from $\mathrm{P}(8 \mathrm{~T})$ upwards. Data from this study show that the base of the Upper Jurassic must be redefined as from $\mathrm{P}(8 \mathrm{~B})$ upwards. Since the lower deposits of the Cabaços Formation have no age-diagnostic fossils, it is not possible to rule out the possibility that some of these beds encompass the latest Callovian and/or earliest Oxfordian time.

The calcareous nannofossil assemblages from Pedrógão reported below (Fig. 3) confirm a late Callovian age consistent with the athleta ammonite Zone.

\section{Material and methods}

\section{Ostracods}

Fifteen samples were collected from the marly beds of the Cabo Mondego 'formation' at Pedrógão, central-west coast of Portugal (Fig. 1); these samples were subsampled immediately after collection for calcareous nannofossil analysis. The main samples were processed at the Universidade de Lisboa using standard micropalaeontological techniques, including disaggregation with petroleum and washing over $63,150,500 \mu \mathrm{m}$ and $2 \mathrm{~mm}$ sieves. Washed residues were picked for ostracods, usually $75 \%$ random splits of the $>150 \mu \mathrm{m}$ fractions obtained with a microsplitter. Abundance patterns in the range chart (Fig. 4) are recalculated from the data. Scanning electron miocroscope and light microscope images were prepared in the Senckenberg Forschungsinstitut und Naturmuseum, Frankfurt-am-Main and in the Faculdade de Ciências, Universidade de Lisboa.

During the course of the work type and comparative materials housed in the Bundesanstalt für Geowissenschaften und Rohstoffe, 


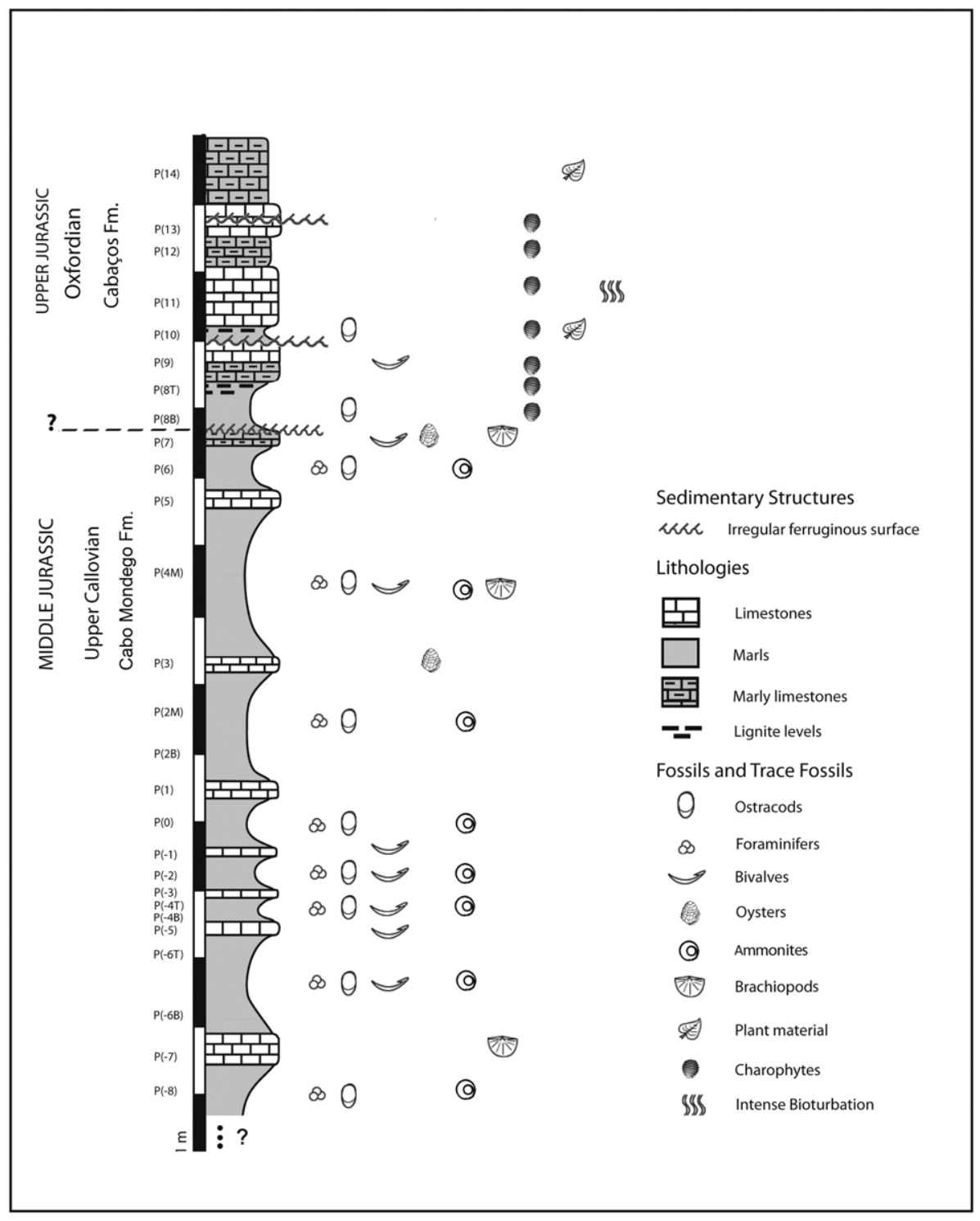

Fig. 2. Lithological log of Pedrógão section with sample points. Ammonite data based on Ruget-Perrot (1961).
Berlin, the Natural History Museum, London and in the Senckenberg Forschungsinstitut und Naturmuseum, Frankfurt-amMain were consulted and are discussed in the Systematic Palaeontology below.

Type and figured material from the present work is housed in the Senckenberg Forschungsinstitut und Naturmuseum, Frankfurt-amMain and bears the catalogue numbers 'SMF Xe' of the Ostracod Collection. A set of comparative material is housed in the Departamento de Geologia, Faculdade de Ciências, Universidade de Lisboa.

Abbreviations: LV, left valve; RV, right valve; V, valve; $\mathrm{C}$,

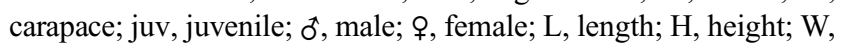
width in $\mathrm{mm}$.

\section{Calcareous nannofossils}

\section{Preparation and counting}

Simple smear-slides for light microscopic examination were prepared following standard procedures (e.g. Bown \& Young 1998). Each smear slide was subsampled from the $1 \mathrm{~cm}^{3}$ bulk sediment sample. A small fraction of sediment (3-6 'grains') and a few drops of tap water were placed on to a glass microscope slide $(76 \times 26 \mathrm{~mm})$, the sediment was crushed in the water and 'smeared' thinly across the surface of the glass slide using a plastic stirring rod, until a thin layer of rippled material was obtained. The slide was then dried on a hotplate. After drying, a glass coverslip $(50 \times 22 \mathrm{~mm})$ was attached on to the glass slide using Norland Optical Adhesive 61 as the mounting medium, air bubbles were removed by gentle pressure, and the preparation cured under long-wave UV light for $10 \mathrm{~min}$.

The counts of the nannofossil assemblages (Fig. 3) were performed on 100 different fields of view (FOV) in all slides using an Olympus BX40 polarizing light-microscope at a magnification of $1000 \times$. In each slide, different FOV were analysed and counted first 'systematically', following predefined traverses along the slide, and then along random traverses on each slide. Only nannofossils that were completely within the FOV, and specimens which had their base-point within the FOV were counted (i.e. nannofossils that are truncated at the top edge of the FOV; specimens truncated at the lower edge of the FOV were not included in the counts) in order to avoid a size bias. Studied slides are housed in the collections of Network Stratigraphic Consulting Ltd.

\section{Age determination}

Reference is made to the 'standard' Middle to Late Jurassic nannofossil zonation of Bown \& Cooper (1998) for age determination and zone assignment. This NJ (Nannofossil Jurassic) notation is an accepted standard that (at the time) stabilized biostratigraphic nomenclature for the Jurassic. The Bown et al. (1988) zonation scheme includes reference to 


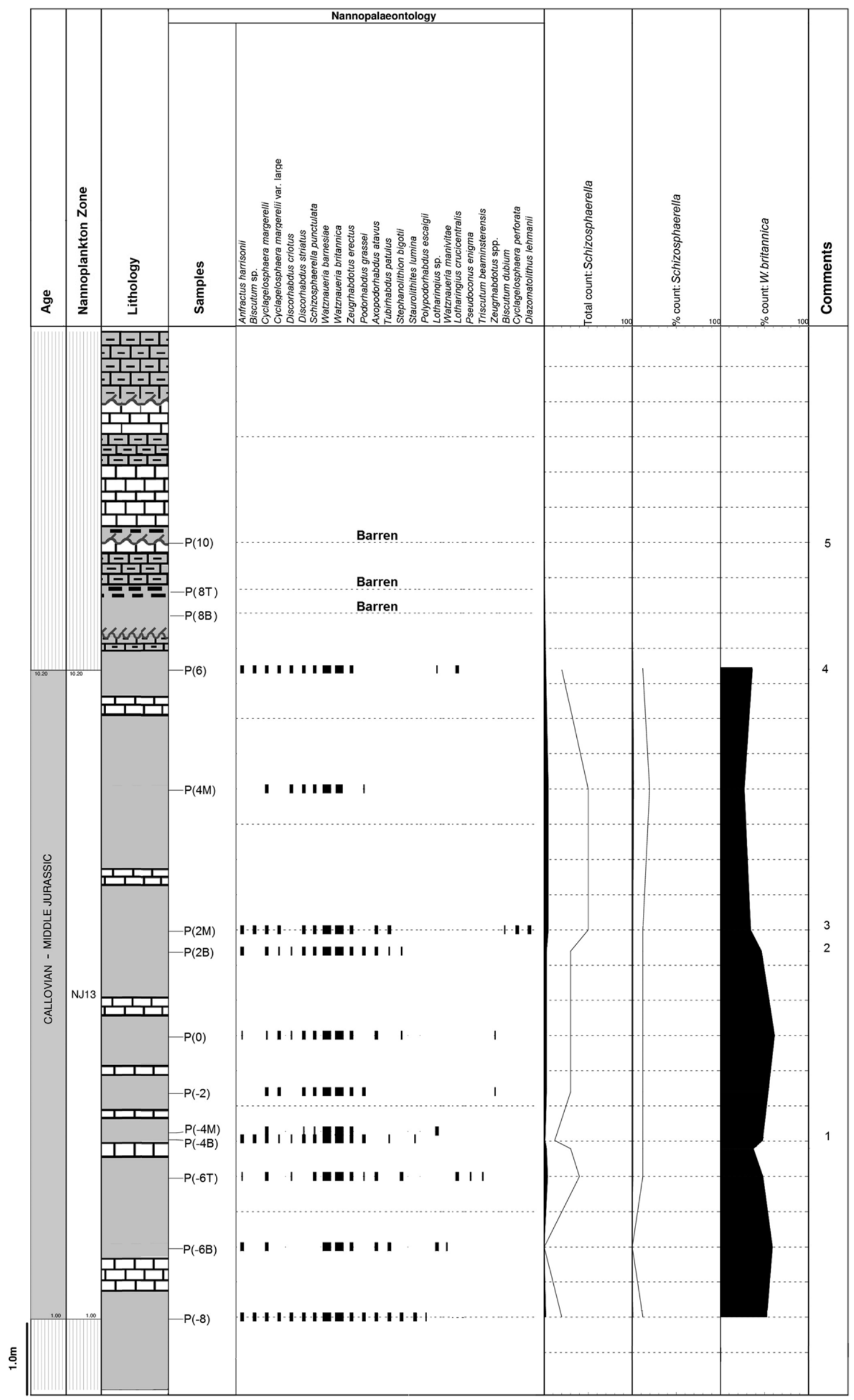

Fig. 3. Calcareous nannofossil range chart. Notes: 1. Last Occurrence Datum (LOD) S. lumina; 2. LOD St. bigotii; 3. LOD A. atavus, D. lehmanii; 4. LOD An. harrisonii, C. margerelii, L. crucicentralis, Sc. punctulata, Z. erectus; 5. highly organic, non-calcareous. 


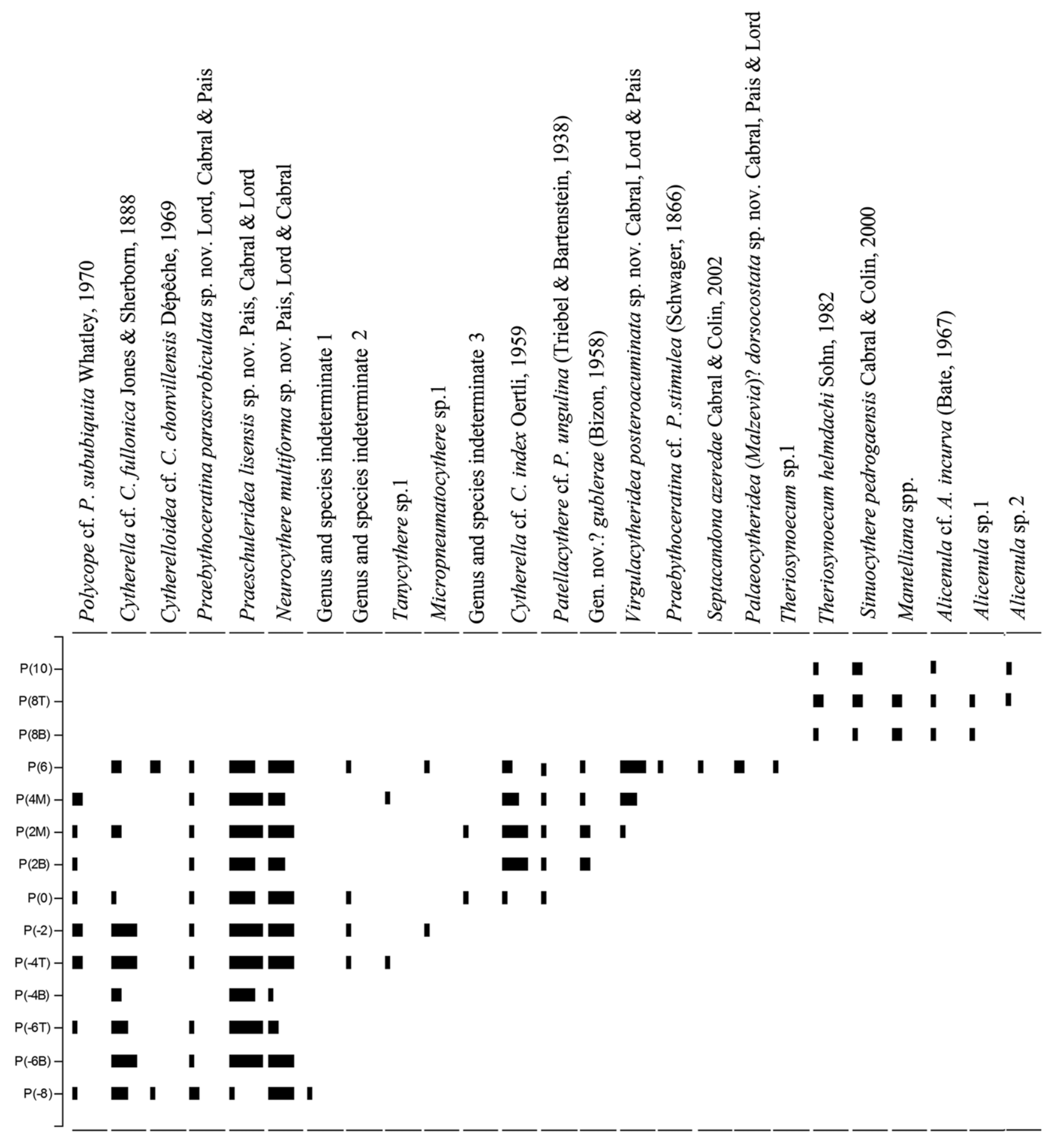

$>201 \square 86-200$

46-85 $\mathbf{\square} 11-45 \mathbf{I 1 - 1 0}$

Fig. 4. Ostracod range chart.

Portugal and is the basis for the 1998 scheme of Bown \& Cooper (in Bown 1998). This zonation is calibrated against Boreal ammonite zones and Tethyan nannofossil zones of Bralower et al. (1989) and achieves a resolution at least equal to the ammonite zonation. There is little relevant recent published nannofossil data for the CallovianOxfordian of Portugal; however, further reference is made to Jain (2008), Bergen et al. (2013) and Castellato (2010).

\section{Ostracod systematic palaeontology}

The classification of Quaternary-living ostracods of Horne et al. (2002) is followed with additions appropriate for Mesozoic assemblages.
Class Ostracoda Latreille, 1806 Order Myodocopida Sars, 1866 Suborder Cladocopina Sars, 1866 Family Polycopidae Sars, 1866

Genus Polycope Sars, 1866

Type species. Polycope orbicularis Sars, 1866.

Remarks. The generic concept of Polycope is applied in the broadest sense. In the Jurassic, specimens of Polycope are rarely sufficiently abundant or well preserved for reliable species identification or comparison. 


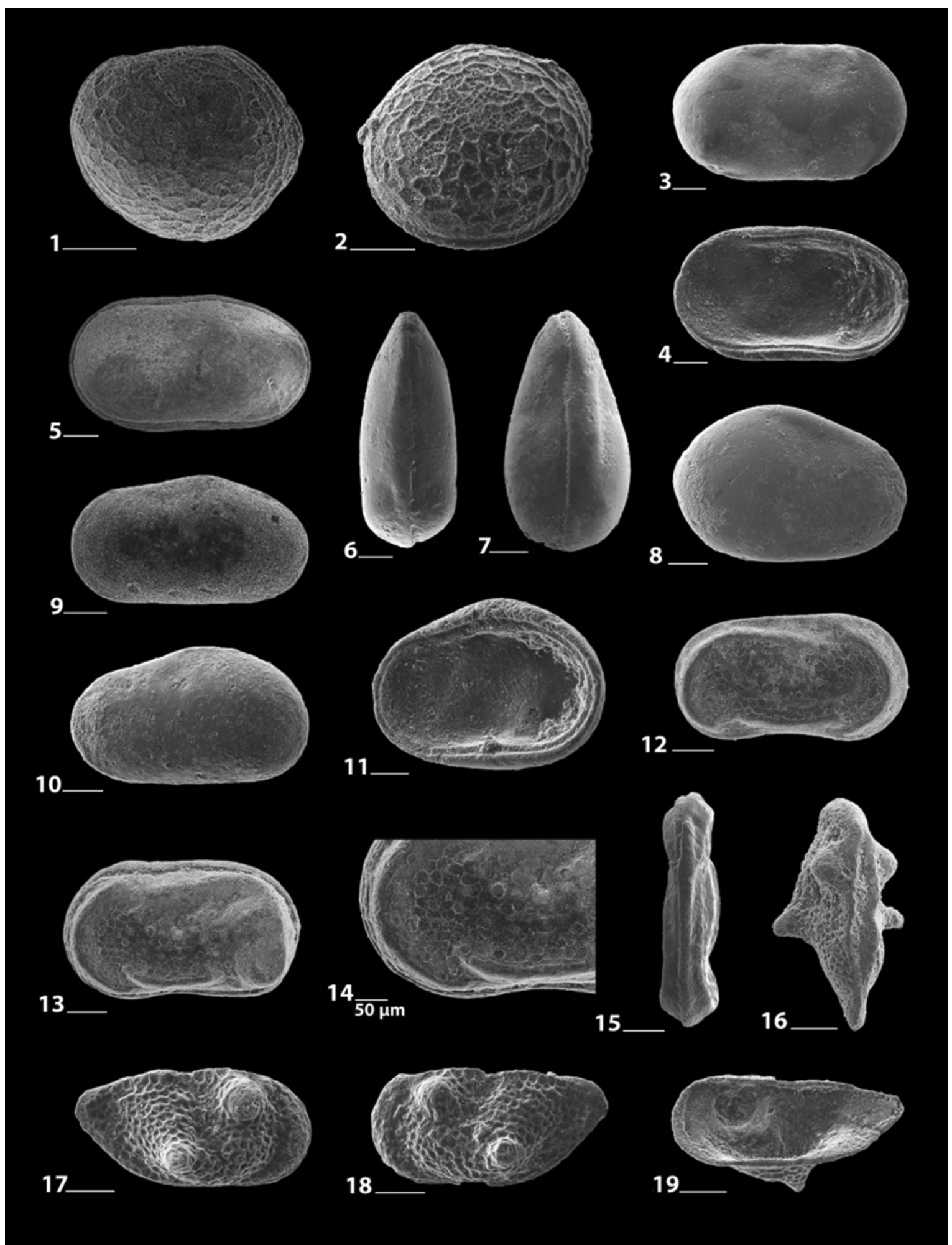

Fig. 5. (1, 2) Polycope cf. P. sububiquita Whatley, 1970: 1, C, right view, external, SMF Xe 23173, P(-2), Upper Callovian, Pedrógão, Portugal L =0.324, $\mathrm{H}=0.274 ; 2$, C, left view, external, SMF Xe 23174, $\mathrm{P}(2 \mathrm{M})$, Upper Callovian, Pedrógão, Portugal, $\mathrm{L}=0.375, \mathrm{H}=0.324$. (3 - 6) Cytherella cf. C. fullonicaJones \& Sherborn, 1888: 3, o RV, external, SMF Xe 23175, P(-2), Upper Callovian, Pedrógão, Portugal, L =0.650, H=0.375; 4, 아 RV, internal, SMF Xe 23176, P(-2), Upper Callovian, Pedrógão, Portugal, $\mathrm{L}=0.675, \mathrm{H}=0.375 ; 5$, o C, left view, SMF Xe 23177, $\mathrm{P}(-2)$, Upper Callovian, Pedrógão, Portugal, $\mathrm{L}=0.650, \mathrm{H}=0.350 ; \mathbf{6}$, o C, ventral view, SMF Xe 23178, $\mathrm{P}(-2)$, Upper Callovian, Pedrógão, Portugal, $\mathrm{L}=0.675, \mathrm{H}=0.375$. (7-11) Cytherella cf. C. index Oertli, 1959: 7, o C, dorsal view, SMF Xe 23179, P(2M), Upper Callovian, Pedrógão, Portugal, L =0.600, H=0.425; 8, ㅇ RV, external, SMF Xe 23180, P(0), Upper Callovian, Pedrógão, $\mathrm{L}=0.600, \mathrm{H}=0.400 ; 9$, đ LV, external, SMF Xe 23181, P(6), Upper Callovian, Pedrógão, Portugal, $\mathrm{L}=$ 0.550, H = 0.274; 10, ᄋ LV, external, SMF Xe 23182, P(0), Upper Callovian, Pedrógão, Portugal, L = 0.575, H=0.324; 11, ᄋ RV, internal, SMF Xe 23183, $\mathrm{P}(0)$, Upper Callovian, Pedrógão, Portugal, $\mathrm{L}=0.624, \mathrm{H}=0.425$. (12-15) Cytherelloidea $\mathrm{cf}$. C. chonvillensis Dépêche, 1969: 12, đ̊ C, right view, external, SMF Xe 23184, P(6), Upper Callovian, Pedrógão, Portugal, L =0.525, H =0.300; 13, ๆ C, left view, external, SMF Xe 23185, P(6), Upper Callovian, Pedrógão, Portugal, $\mathrm{L}=0.575, \mathrm{H}=0.324 ; \mathbf{1 4}$, $\mathrm{C}$ (as 13), ornament detail; 15, ơ C, dorsal view, SMF Xe 23186, P(6), Upper Callovian, Pedrógão, Portugal, $\mathrm{L}=0.550 \mathrm{H}=0.324$. (16-19) Praebythoceratina parascrobiculata sp. nov. Lord, Cabral \& Pais: 16, C, dorsal view, paratype, SMF Xe 23187 , P(2B), Upper Callovian, Pedrógão, Portugal, L = 0.476, H = 0.250; 17, RV, external, holotype, SMF Xe 23188, P(2B), Upper Callovian, Pedrógão, Portugal, $\mathrm{L}=0.476, \mathrm{H}=0.250 ; 18, \mathrm{LV}$, external, paratype, SMF Xe 23189, $\mathrm{P}(2 \mathrm{M})$, Upper Callovian, Pedrógão, Portugal, $\mathrm{L}=0.476, \mathrm{H}=0.250 ; 19, \mathrm{RV}$, internal, paratype, SMF Xe 23190, P(2M), Upper Callovian, Pedrógão, $\mathrm{L}=0.500, \mathrm{H}=0.250$. Scale bars $100 \mu \mathrm{m}$ except where otherwise noted. 


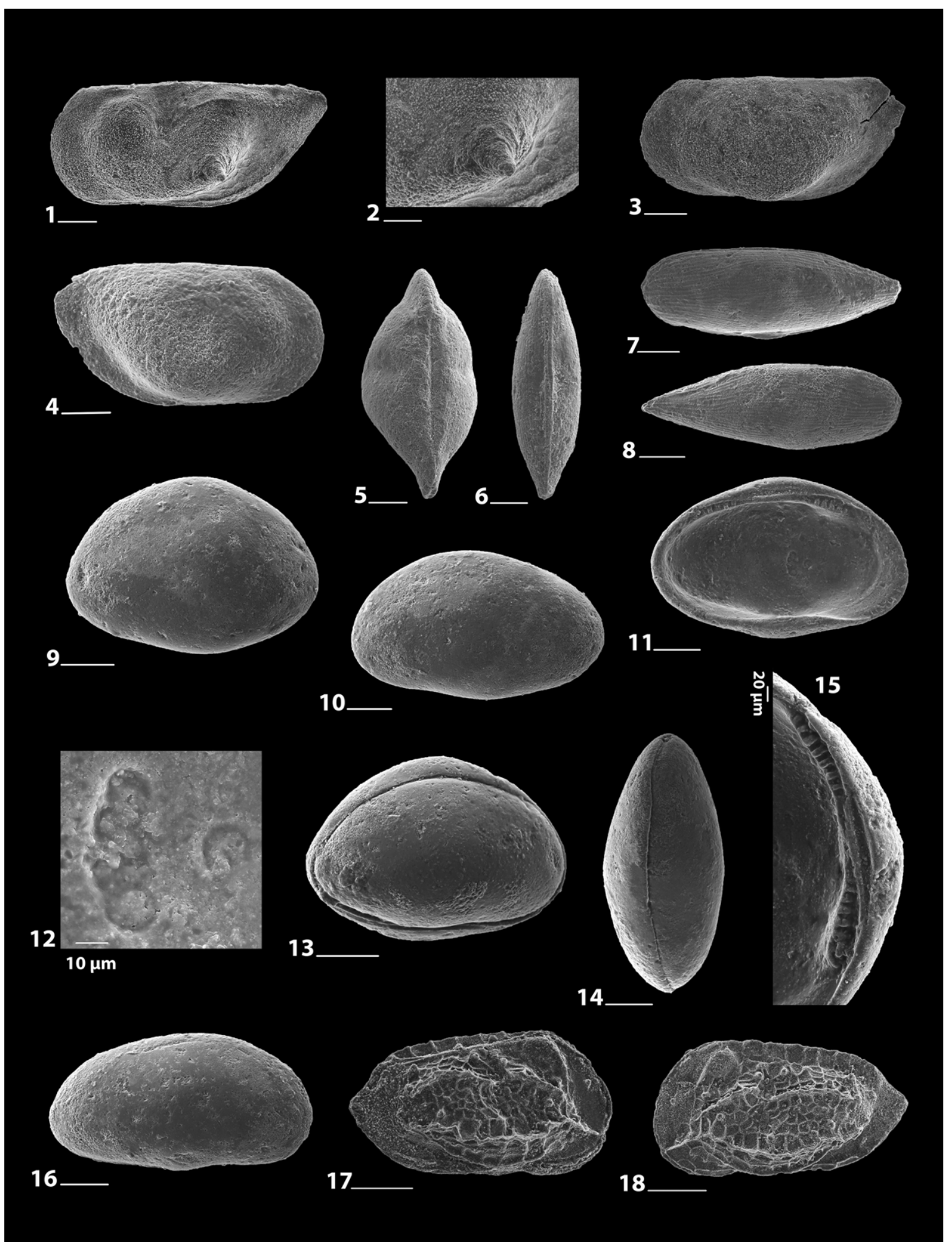

Fig. 6. (1, 2) Praebythoceratina cf. P. stimulea (Schwager, 1866): 1, LV, external, SMF Xe 23195, P(6), Upper Callovian, Pedrógão, Portugal, L =0.650, $\mathrm{H}=0.3$; 2, LV (as 1), external, spine detail. (3 - 5) Patellacythere cf. P. ungulina (Triebel \& Bartenstein, 1938): 3, LV, external, SMF Xe 23196, P(6), Upper Callovian, Pedrógão, Portugal, L = 0.591, H=0.3; 4, RV, external, SMF Xe 23197, P(2B), Upper Callovian, Pedrógão, Portugal, $\mathrm{L}=0.550, \mathrm{H}=$ 0.274; 5, C, dorsal view, SMF Xe 23198, P(2B), Upper Callovian, Pedrógão, Portugal, L =0.6, H=0.3. (6-8) Tanycythere sp. 1: 6, C, dorsal view, SMF Xe 23199, P(-4T), Upper Callovian, Pedrógão, Portugal, L =0.6, H=0.225; 7, C (as 6), left view; 8, C, right view, external, SMF Xe 23200, P(4M), Upper Callovian, Pedrógão, Portugal, $\mathrm{L}=0.575, \mathrm{H}=0.2$. (9-16) Praeschuleridea lisensis sp. nov. Pais, Cabral \& Lord: 9, o LV, external, paratype, SMF Xe 23201, P(-2), Upper Callovian, Pedrógão, Portugal, L = 0.476, H=0.324; 10, o LV, external, paratype, SMF Xe 23202, $\mathrm{P}(-2)$, Upper Callovian, Pedrógão, Portugal, $\mathrm{L}=0.550, \mathrm{H}=0.324 ; 11$, o $\mathrm{LV}$, internal, paratype, SMF Xe 23203, $\mathrm{P}(2 \mathrm{~B})$, Upper Callovian, Pedrógão, $\mathrm{Portugal}, \mathrm{L}=0.5, \mathrm{H}=0.3 ; 12$, ot LV (as 11), internal, muscle scars detail; 13, o C, right view external, holotype, SMF Xe 23204, P(2B), Upper Callovian, Pedrógão, Portugal, L =0.425, $\mathrm{H}=0.324 ; 14$, $\subsetneq \mathrm{C}$, dorsal view, paratype, SMF Xe 23205, P(2B), Upper Callovian, Pedrógão, Portugal, $\mathrm{L}=0.5, \mathrm{H}=0.324 ; 15$, $\mathrm{LV}$, internal, paratype, hinge detail, SMF Xe 23206, P(2B), Upper Callovian, Pedrógão, Portugal, L =0.450, H = 0.324; 16, ơ RV, external, paratype, SMF Xe 23207, $\mathrm{P}(-2)$, Upper Callovian, Pedrógão, Portugal, $\mathrm{L}=0.525, \mathrm{H}=0.3$. $(\mathbf{1 7}, \mathbf{1 8})$ Palaeocytheridea (Malzevia)? dorsocostata sp. nov Cabral, Pais \& Lord: 17, ᄋ C, right view, external, holotype, SMF Xe 23208, P(6), Upper Callovian, Pedrógão, Portugal, L =0.4, H=0.250; 18, o LV, external, female, paratype, SMF Xe 23209, $\mathrm{P}(6)$, Upper Callovian, Pedrógão, Portugal, $\mathrm{L}=0.450, \mathrm{H}=0.250$. Scale bars $100 \mu \mathrm{m}$ except where otherwise noted. 
Polycope cf. P. sububiquita Whatley, 1970 (Fig. 5:1-2)

cf. 1970 Polycope sububiquita Whatley: 312-313, pl. 1, figs 5-11, 15. cf. 2009 Polycope sububiquita Whatley; Wilkinson \& Whatley: 260, pl. 1, fig. 3 .

Material. 60 specimens - adults and juveniles, carapaces: samples $\mathrm{P}(-8), \mathrm{P}(-6 \mathrm{~T}), \mathrm{P}(-4 \mathrm{~T}), \mathrm{P}(-2), \mathrm{P}(0), \mathrm{P}(2 \mathrm{~B}), \mathrm{P}(2 \mathrm{M}), \mathrm{P}(4 \mathrm{M})$.

Description. Sublenticular outline with small dimensions; valves of similar size; greatest length at mid-height, greatest height at anterior cardinal angle, greatest width at mid-height and length. Dorsal margin slightly convex or straight, less than total length of valve; ventral margin strongly convex; anterior margin inclined at mid-height and above; posterior margin asymmetrically rounded. Anterior and posterior cardinal angles obtuse. Ornament reticulate, sometimes relatively weak or occasionally with stronger radial ribs towards the margins. Internal details and sexual dimorphism not observed.

Dimensions. $\mathrm{L}=0.250-0.425, \mathrm{H}=0.200-0.325$.

Occurrence. Lamberti-mariae zones, Callovian-Oxfordian, Staffin Bay and mariae Zone, Oxfordian, Port-en-Righ, Scotland; holotype from mariae Zone, Woodham, England (Whatley 1970). Athleta Zone to glosense Zone, Upper Callovian-Middle Oxfordian, England (Wilkinson \& Whatley 2009). Athleta Zone, Upper Callovian, Pedrógão (this work).

Remarks. Whatley (1970) cites a number of records of similar Jurassic age in synonymy with $P$. sububiquita but these are unreliable because of poor illustrations. Polycope sp. 11 of Bizon (1958) is not illustrated and Polycope sp. 11 Bizon in Oertli (1959) is illustrated by a single image with no distinguishing features; the same species figured by Glashoff (1964, pl. 5, fig. 22) resembles Oertli's figure in having a rounded outline and apparently lacking ornament. Polycope sp. 12 of Glashoff (1964, pl. 5, fig. 21) resembles $P$. sububiquita in outline and appears ornamented. Also synonymized is Polycope sp. A of Donze (1962) which has a more rounded outline than sububiquita and has weak or no ornament. We have compared our material directly with the specimen figured by Wilkinson \& Whatley (2009, catalogue number Io 5032 from the type locality) which is similar in shape, size and ornament.

Subclass Podocopa Sars, 1866

Suborder Platycopina Sars, 1866

Family Cytherellidae Sars, 1866

Genus Cytherella Jones, 1849

Type species. Cytherina ovata Roemer, 1841.

Remarks. Numerous fossil species of Cytherella have been described, differentiation of which has generally relied on a subjective assessment of three-dimensional shape, as a result of which the taxa have little biostratigraphical or palaeoecological utility and formal description of new 'species' is of little value.

\section{Cytherella cf. C. fullonica Jones \& Sherborn, 1888}

(Fig. 5:3-6)

cf. 1888 Cytherella fullonica Jones \& Sherborn: 274, pl. 1, figs 12a-c. cf. 1969 Cytherella fullonica Jones \& Sherborn; Bate: 395, pl. 5, fig. 9 , pl. 6 , fig. 1 . cf. 1970 Cytherella fullonica Jones \& Sherborn; Whatley: 313, pl. 1, figs $12-14,16,18$.

cf. 1978 Cytherella fullonica Jones \& Sherborn; Kilenyi: pl. 1, figs 1-2.

cf. 1995 Cytherella cf. fullonica Jones \& Sherborn; Mette: 266, pl. 1, figs $1-4$.

cf. 2009 Cytherella fullonica Jones \& Sherborn; Wilkinson \& Whatley: 260, pl. 1, figs 4, 5 .

Material. 460 specimens - adults and juveniles, valves and carapaces: samples $\mathrm{P}(-8), \mathrm{P}(-6 \mathrm{~B}), \mathrm{P}(-6 \mathrm{~T}), \mathrm{P}(-4 \mathrm{~B}), \mathrm{P}(-4 \mathrm{~T})$, $\mathrm{P}(-2), \mathrm{P}(0), \mathrm{P}(2 \mathrm{M}), \mathrm{P}(6)$.

Description. Subrectangular and elongate outline with large dimensions; RV totally overlaps LV; greatest length at mid-height, greatest height at antero-dorsal margin, greatest width near posterior margin. Dorsal margin straight to slightly concave, roughly parallel with the straight to weakly concave ventral margin, anterior margin uniformly rounded, posterior margin rounded in larger RV and may be angled near mid-height in smaller LV but in both valves there is a clear postero-dorsal slope to the margin. Valve surface smooth and unornamented. Sexual dimorphism evident, with males slightly smaller, narrower, with less pronounced overlap of the valves. Internally the larger RV has a contact groove to receive the smaller LV. Muscle scars well preserved and typical for genus.

Dimensions. $九$ : $\mathrm{L}=0.590-0.670, \mathrm{H}=0.350-0.370$. ㅇ: $\mathrm{L}=0.650$ $0.720, \mathrm{H}=0.375-0.400$.

Occurrence. Described from the Bathonian of England (Jones \& Sherborn 1888) and redescribed with a lectotype and paralectotypes designated by Bate (1969). Ranges from the Bathonian to Lower Kimmeridgian (Wilkinson \& Whatley 2009). Athleta Zone, Upper Callovian, Pedrógão (this work).

Remarks. The lectotypic material figured by Bate (1969) shows a weak median depression not present in our material but the lectotypic specimens and our material share a sloping postero-dorsal margin. The Pedrógão material is closer to the specimens from the Lower Kimmeridgian figured by Kilenyi (1978). Cytherella fullonica is known from Great Britain and from the Bathonian of Normandy (F. Dépêche, 1964, Université Pierre-et-Marie Curie, Paris, unpublished thesis); the present record from Portugal suggests a wider palaeobiogeographical range than previously understood.

Measurement of our material revealed sexual dimorphism in A-1 instars with $0^{*}: \mathrm{L}=0.570-0.590, \mathrm{H}=0.330-0.350$; 9 : $\mathrm{L}=0.570$ $0.610, \mathrm{H}=0.340-0.360$ (gender determination based on $\$$ posterior inflation); material in Figure 5:3-6 is adult (A) stage.

$$
\text { Cytherella cf. C. index Oertli, } 1959
$$

(Fig. 5:7-11)

cf. 1958 Cytherella sp. 17 Bizon: 21, pl. 5, figs 7-9.

cf. 1959 Cytherella index Oertli: 16-17, pl. 1, figs 13-25.

cf. 1963 Cytherella index Oertli; Grékoff: 1720, pl. 1, figs 6-9.

cf. 1966 Cytherella index Oertli; Oertli in Maync: 13, pl. 9, figs 7-9.

cf. 1991 Cytherella index Oertli; Rosenfeld \& Honigstein: 435, pl. 1, fig. 3 .

cf. 1995 Cytherella cf. index Oertli; Mette: 266, pl. 1, figs 5-8. cf. 2004 Cytherella index Oertli; Mette \& Geiger: 81, pl. 9, figs 3, 4. cf. 2009 Cytherella index Oertli; Wilkinson \& Whatley: 262, pl.1, fig. 6.

Material. 245 specimens - adults and juveniles, valves and carapaces: samples $\mathrm{P}(0), \mathrm{P}(2 \mathrm{~B}), \mathrm{P}(2 \mathrm{M}), \mathrm{P}(4 \mathrm{M}), \mathrm{P}(6)$. 
Description. Suboval outline with relatively large dimensions; RV totally overlaps smaller LV; greatest length at mid-height, greatest height slightly posterior of mid-length, greatest width towards posterior. Dorsal margin strongly convex, sloping towards anterior margin from point of greatest valve height with a weak concavity, ventral margin straight to slightly convex, anterior and posterior margins well rounded with an angulation of the posterior margin at about mid-height sometimes evident. Valve surface smooth and unornamented. Sexual dimorphism evident, with males relatively more elongate than females. Internally the larger RV has a contact groove to receive the smaller LV; muscle scars not seen.

Dimensions. $\sigma^{*}: \mathrm{L}=0.550-0.600, \mathrm{H}=0.274-0.350$. ㅇ: $\mathrm{L}=0.525-$ $0.600, \mathrm{H}=0.300-0.400$.

Occurrence. Described originally from the Oxfordian of the Swiss Jura (Oertli 1959), C. index is known from the Paris Basin (Bizon 1958) and with Tethyan records from the ?Bathonian to Oxfordian of Israel (Oertli in Maync 1966) and the Callovian of Madagascar (Grékoff 1963; Mette \& Geiger 2004). Upper Callovian, Vermoil (Cabral et al. 2003). Athleta Zone, Upper Callovian, Pedrógão (this work).

Remarks. Tethyan records cited above are remarkably convincing given that they are based only on subjective comparison of threedimensional shape. It is, however, surprising that Bate (1975) did not find the species in the Callovian-Tithonian of Tanzania. Our material shows some posterior margin shape variation.

Genus Cytherelloidea Alexander, 1929

Type species. Cytherella williamsoniana Jones, 1849.

Cytherelloidea cf. C. chonvillensis Dépêche, 1969 (Fig. 5:12-15)

cf. 1969 Cytherelloidea chonvillensis Dépêche: 266-267, pl. 2, figs $1,2$.

cf. 1984 Cytherelloidea sp. Herngreen et al.: pl. 5, fig. 14. cf. 2009 Cytherelloidea chonvillensis Dépêche; Franz et al.: 131, pl. 1 , fig. 3 .

Material. 27 specimens - adults, valves and carapaces: samples $\mathrm{P}$ $(-8), \mathrm{P}(6)$.

Description. Subrectangular outline, medium size; RV overlaps LV; greatest length at mid-height, greatest height towards anterior, greatest width at mid-length. Dorsal margin straight to slightly concave, ventral margin concave but overall parallel with dorsal margin, anterior and posterior margins evenly rounded. Lateral surface with four primary ribs: one bordering the anterior margin; a short one, curved, close to and parallel with ventral margin; a third rib runs around the posterior margin and along the dorsal margin terminating near the antero-dorsal border behind the anterior marginal rib; a weaker rib runs from the postero-dorsal towards the mid-valve area where a swelling corresponds to the position of the muscle scars internally; a secondary reticulate ornament is present (Fig. 5:14). Sexual dimorphism present, with females having two vertical posterior swellings and a more quadrate posterior margin. Internal features not observed.

Dimensions. $\sigma^{\star} \mathrm{L}=0.500-0.575, \mathrm{H}=0.250-0.300$. 우 $\mathrm{L}=0.500$ $0.525, \mathrm{H}=0.250-0.300$.

Occurrence. Described from the Callovian of the Paris Basin (Dépêche 1969) and reported from the Callovian of The
Netherlands (Herngreen et al. 1984) and SW Germany (Franz et al. 2009). Athleta Zone, Upper Callovian, Pedrógão (this work).

Remarks. Our material is similar to Cytherelloidea chonvillensis but differs in the configuration of the primary ornament, especially in the development of the ventral rib.

Order Podocopida Sars, 1866

Superfamily Cytheroidea Baird, 1850

Family Bythocytheridae Sars, 1926

Remarks. The genus Monoceratina Roth (Devonian-Permian) was, for a long time, used as a repository for cytheroid ostracods with a straight dorsal margin and a posterior margin terminating close to the dorsal margin and posterior cardinal angle. More recent work (Gründel \& Kozur 1971; Kozur 1972; Schornikov 1990) has demonstrated a variety of carapace shapes and internal features in post-Palaeozoic ostracods with this bauplan, in particular taxa that can be seen to be related to, but differ in carapace characteristics from, the living genus Bythocythere Sars. A number of Mesozoic genera have been recognized by Gründel \& Kozur (1971) and Kozur (1972) and we have followed their taxonomy; however, the taxa are generally poorly defined and figured. The valuable review of Schornikov (1990) has gone some way to making sense of the situation but further work is needed at the level of individual genera.

Genus Praebythoceratina Gründel \& Kozur, 1971

Type species. Bythoceratina progracilis Kozur, 1972.

Praebythoceratina parascrobiculata sp. nov. Lord, Cabral \& Pais (Fig. 5:16-19)

Etymology. From its resemblance to Monoceratina scrobiculata Triebel \& Bartenstein, 1938.

Diagnosis. A species of Praebythoceratina characterized by a sinuous dorsal margin with a mid-length concavity coinciding with a median sulcus and inclined down towards the posterior extremity, and reticulate surface ornamentation.

Types. Holotype: RV, SMF Xe 23188, Figure 5:17. Paratypes: C, SMF Xe 23187, Figure 5:16; LV, SMF Xe 23189, Figure 5.18; RV, SMF Xe 23190, Figure 5:19, and four unfigured paratypes SMF Xe $23191-23194$.

Material. 47 specimens - adults, valves and carapaces: samples $\mathrm{P}(-8), \mathrm{P}(-6 \mathrm{~B}), \mathrm{P}(-6 \mathrm{~T}), \mathrm{P}(-4 \mathrm{~T}), \mathrm{P}(-2), \mathrm{P}(0), \mathrm{P}(2 \mathrm{~B}), \mathrm{P}(2 \mathrm{M})$, $\mathrm{P}(4 \mathrm{M}), \mathrm{P}(6)$.

Description. Relatively quadrate outline tapering posteriorly, medium size; LV and RV of similar size with minimal overlap; greatest length dorsal of mid-height, greatest height at one-third length from anterior, greatest width behind mid-length at position of ventral spinose inflation. Dorsal margin sinuous with a mid-length concavity and inclined downwards posteriorly toward the tapered posterior margin, posterior extremity above mid-height but below line of dorsal margin and may be a caudal process; anterior margin symmetrically rounded and stands out due to a curved furrow parallel to the margin which defines a marginal rim, ventral margin straight with a wellmarked angle to the posterior margin. Surface morphology of a median sulcus with two adjacent oblique swellings, one spinose swelling postero-ventrally and a tubercle located antero-dorsally. Sexual dimorphism not seen. Hingement lophodont, comprising 
terminal sockets and a median bar in LV and complementary structures in RV, all appear smooth but hingement poorly preserved. Calcified inner lamella narrow; other internal details not observed.

Dimensions. $\mathrm{L}=0.450-0.550, \mathrm{H}=0.200-0.275$.

Occurrence. Athleta Zone, Upper Callovian, Pedrógão (this work).

Remarks. Monoceratina scrobiculata Triebel \& Bartenstein, 1938 should now be classified as Praebythoceratina scrobiculata (T\&B) as it has the median dorsal sulcus and postero-ventral spine characteristic of Praebythoceratina. The line drawings of scrobiculata in Triebel \& Bartenstein (1938, pl. 1, figs 5a, b; pl. 2, fig. 6) are very accurate when compared with the holotype (Senckenberg X/ع 133a), and scrobiculata (T\&B) sensu stricto clearly differs from parascrobiculata $\mathrm{sp}$. nov. in showing a straight dorsal margin with the posterior margin steeply inclined dorsally and terminating at the postero-dorsal margin; $P$. scrobiculata is significantly larger than our material (holotype $\mathrm{L}=$ $0.67, \mathrm{H}=0.35$ ). Bythoceratina (Praebythoceratina) scrobiculata (T\&B) from the Callovian of Poland figured by Olempska \& Błaszyk (2001, fig. 13a-d) is not scrobiculata but is closer to parascrobiculata sp. nov., although differing in L:H ratio, outline of dorsal margin and possessing a relatively swollen postero-dorsal area. Similarly scrobiculata from the Oxfordian of England figured by Whatley (1970, pl. 3, figs $1-7,9,19)$ is not scrobiculata s.s. but does resemble parascrobiculata in having a comparable L:H ratio, a sinuous dorsal margin and a posterior margin terminating below the line of the dorsal margin; however, the ventral margin is concave and in two of the figured specimens the postero-ventral spine extends below the valve margin. Praebythoceratina 'scrobiculata' has been widely reported from the Jurassic of Western Europe and clearly represents a cryptotaxonomy.

\section{Praebythoceratina $\mathrm{cf}$ P. stimulea (Schwager, 1866)} (Figure 6:1-2)

cf. 1866 Cythereis stimulea Schwager, in Oppel \& Waagen: 276, fig 1. cf. 1938 Monoceratina stimulea (Schwager); Triebel \& Bartenstein: 505-506, pl. 1, figs 1-2.

cf. 1970 Monoceratina stimulea (Schwager); Whatley: 319, pl. 3 , figs $8,11-17$.

cf. 2009 Monoceratina stimulea (Schwager); Wilkinson \& Whatley: 263, pl. 1, figs 15-16.

Material. 1 adult LV, 2 adult V fragments - same bed as sample $\mathrm{P}(6)$ of this work, sampled laterally (1998).

Description. Sub-rectangular outline tapering posteriorly, medium size; greatest length dorsal of mid-height, greatest height immediately posterior of mid-length, greatest width posterior at position of ventral spine. Dorsal margin straight, posterior margin extended with extremity close to the dorsal margin, anterior margin symmetrically rounded, ventral margin slightly convex anteriorly and posteriorly, with a midlength concavity. Antero- and postero-marginal areas strongly depressed. Morphology of the valve with a prominent median sulcus and a large ventro-lateral spine. Surface almost smooth, with two weak curved ribs postero-dorsally, annular costae around the spine and very weak reticulation at its base. Sexual dimorphism not observed. Hinge adont, with a narrow groove in the RV, which seems crenulate; complementary bar in the LV. Calcified inner lamella narrow with small anterior and posterior vestibules; other internal details not observed.

Dimensions. $\mathrm{L}=0.650, \mathrm{H}=0.300$.

Occurrence. Praebythoceratina stimulea is known in Germany from the Middle to Upper Jurassic (Triebel \& Bartenstein 1938) and in
Great Britain, in the Lower Oxfordian of England and Scotland (Wilkinson \& Whatley 2009). In Portugal it was first reported and figured by S. Pinto (2008, unpublished Master thesis, Faculty of Sciences, University of Lisbon) in the Upper Toarcian of Rabaçal and Boca da Mata; athleta Zone, Upper Callovian, Pedrógão (this work).

Remarks. As with Monoceratina scrobiculata Triebel \& Bartenstein, M. stimulea should now be classified as Praebythoceratina as it has the dorso-median sulcus and the postero-ventral spine characteristic of that genus. According to Wilkinson \& Whatley (2009), the morphological characteristics of the species stimulea can be variable, especially in the strength of ornamentation and of the median sulcus. However, both the Toarcian and our Callovian material from Portugal and that figured by Wilkinson \& Whatley (2009) differ from the material figured by Triebel \& Bartenstein (1938) in the position, strength and orientation of the mid-ventral spine, which in the type material is a more prominent and ventrally-directed spine extending below the ventral margin. For these reasons we call our material cf. stimulea.

Monoceratina stimulea (Schwager) figured by Fischer (1962, pl. 19, figs 8-9) from the upper Toarcian of SW Germany is of uncertain affinity.

Genus Patellacythere Gründel \& Kozur, 1971

Type species. Monoceratina williamsi Stephenson, 1946.

Patellacythere cf. P. ungulina (Triebel \& Bartenstein, 1938) (Figure 6:3-5)

cf. 1938 Monoceratina ungulina Triebel \& Bartenstein: 506, 508, pl. 1, figs 3, 4 .

Material. 16 specimens - adults and juveniles, carapaces and valves: samples $\mathrm{P}(0), \mathrm{P}(2 \mathrm{~B}), \mathrm{P}(2 \mathrm{M}), \mathrm{P}(4 \mathrm{M})$, and same bed as sample $\mathrm{P}(6)$ of this work, sampled laterally (1998).

Description. Quadrate to subrectangular outline, medium size; LV and RV of similar size with minimal overlap; greatest length dorsal of mid-height, greatest height towards anterior of mid-length, greatest width posterior of mid-length. Dorsal margin straight with marked cardinal angles, anterior margin rounded, ventral margin straight with an angle into the posterior margin which is sub-triangular to a point below the level of the dorsal margin. Adductor sulcus from mid-dorsal margin to mid-valve area, anterior and posterior marginal rims; valve surface smooth and unornamented. Internal features not visible. Sexual dimorphism not observed; however, some specimens are more elongated (males?) than others. Hinge adont, with a smooth bar in LV and the corresponding groove in RV. Marginal zone with narrow calcified inner lamella and presence of a small anterior vestibule; other internal features not visible.

Dimensions. $\mathrm{L}=0.400-0.600, \mathrm{H}=0.250-0.300$.

Occurrence. Athleta Zone, Upper Callovian, Pedrógão (this work).

Remarks. Patellacythere cf. ungulina is similar to P. ungulina (T\&B) s. s. from the Lower Jurassic in outline, development of the median sulcus, and in the swollen mid-ventral area extending to the ventral margin; however, it differs in dorsal view with the position of greatest width posterior of mid-length. Our material is distinguished from Monoceratina vulsa Jones \& Sherborn, 1888; Bate 1969, pl. 7, fig. 5, lectotype; Lower Bathonian) and from Patellacythere paravulsa Brand, 1990; Brand 1990, pl. 2, figs 1215; Upper Bathonian), also figured by Olempska \& Błaszyk (2001, 


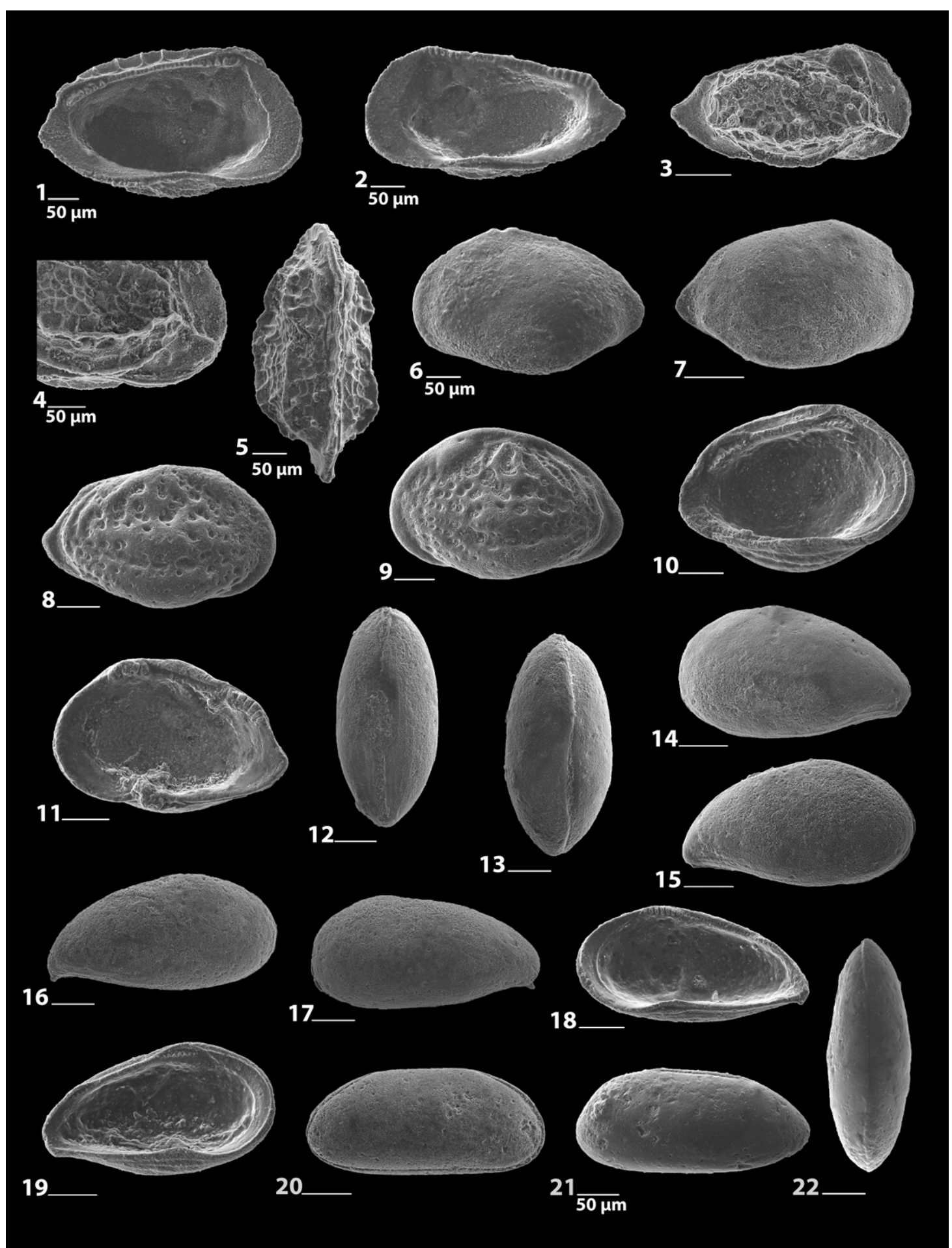

Fig. 7. (1-5) Palaeocytheridea (Malzevia)? dorsocostata sp. nov. Cabral, Pais \& Lord: 1, o LV, internal, paratype, SMF Xe 23210, P(6), Upper Callovian, Pedrógão, Portugal, $\mathrm{L}=0.425, \mathrm{H}=0.250 ; 2$, đ RV, internal, paratype, SMF Xe 23211, $\mathrm{P}(6)$, Upper Callovian, Pedrógão, Portugal, $\mathrm{L}=0.450, \mathrm{H}=0.225 ; 3$, ot RV, external, paratype, SMF Xe 23212, P(6), Upper Callovian, Pedrógão, Portugal, L =0.425, H=0.225; 4, q C (as Fig. 6:17), right view, external,

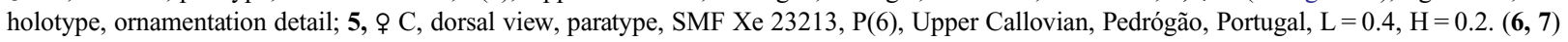
Micropneumatocythere sp. 1: 6, LV, external, SMF Xe 23214, P(6), Upper Callovian, Pedrógão, Portugal, L = 0.4, H=0.225; 7, RV, external, SMF Xe 23215, $\mathrm{P}(6)$, Upper Callovian, Pedrógão, Portugal, $\mathrm{L}=0.375, \mathrm{H}=0.225$. (8-11) Gen. nov.? gublerae (Bizon, 1958): 8, RV, external, SMF Xe 23216, $\mathrm{P}(2 \mathrm{~B})$, Upper Callovian, Pedrógão, Portugal, $\mathrm{L}=0.525, \mathrm{H}=0.350 ;$, LV, external, SMF Xe 23217, $\mathrm{P}(2 \mathrm{~B})$, Upper Callovian, Pedrógão, Portugal, L = 0.550, $\mathrm{H}=0.375 ; 10, \mathrm{LV}$, internal, SMF Xe 23218, P(2B), Upper Callovian, Pedrógão, Portugal, L = 0.525, H=0.375; 11, RV, internal, SMF Xe 23219, $\mathrm{P}(2 \mathrm{~B})$, Upper Callovian, Pedrógão, Portugal, $\mathrm{L}=0.525, \mathrm{H}=0.350$. (12-19) Virgulacytheridea posteroacuminata sp. nov. Cabral, Lord \& Pais: 12, ð $\mathrm{C}$, ventral view, paratype, SMF Xe 23220, P(6), Upper Callovian, Pedrógão, Portugal, $\mathrm{L}=0.575, \mathrm{H}=0.274 ; \mathbf{1 3}$, o C, dorsal view, paratype, $\mathrm{SMF} X \mathrm{Xe} 23221, \mathrm{P}(6)$, Upper Callovian, Pedrógão, Portugal, L = 0.500, H=0.274; 14, \& LV, external, paratype, SMF Xe 23222, P(6), Upper Callovian, Pedrógão, Portugal, L =

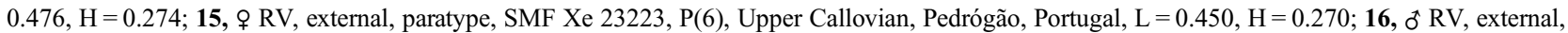
holotype, SMF Xe 23224, P(4M), Upper Callovian, Pedrógão, Portugal, L =0.540, H=0.270; 17, ơ LV, external, paratype, SMF Xe 23225, P(4M), Upper Callovian, Pedrógão, Portugal, $\mathrm{L}=0.540, \mathrm{H}=0.270 ; \mathbf{1 8}$, ${ }^{\star} \mathrm{RV}$, internal, paratype, SMF Xe 23226, $\mathrm{P}(6)$, Upper Callovian, Pedrógão, Portugal, $\mathrm{L}=0.525$, $\mathrm{H}=0.255 ; 19$, ф LV, internal, paratype, SMF Xe 23227, P(6), Upper Callovian, Pedrógão, Portugal, $\mathrm{L}=0.480, \mathrm{H}=0.270$. (20 - 22) Genus and species indeterminate 2: 20, C, right view, SMF Xe 23228, P(-2), Upper Callovian, Pedrógão, Portugal, L =0.4, H = 0.174; 21, C, left view, SMF Xe 23229, P(0), Upper Callovian, Pedrógão, Portugal, $\mathrm{L}=0.450, \mathrm{H}=0.2 ; 22$, C (as 21), dorsal view. Scale bars $100 \mu \mathrm{m}$ except where otherwise noted. 
fig. $13 \mathrm{e}-\mathrm{g}$ ), by its lack of surface ornament and weaker median sulcus. Monoceratina vulsa figured by Bate (1963, pl. 3, figs 5-12) is similar to our material in outline and surface morphology but has a reticulate ornament.

Genus Tanycythere Cabral, Lord, Boomer \& Malz, 2014

Type species. Tanycythere caudata Cabral, Lord, Boomer \& Malz, 2014.

Remarks. The disjunct stratigraphical and geographical record of Tanycythere reported by Cabral et al. (2014) is supplemented by the species below, and also by the recognition that Cytherura striatoides Bonnema, 1941 from the Upper Cretaceous of The Netherlands (Bonnema 1941), Baltic coast of Germany (Herrig 1966) and England (Weaver 1982) may also belong to Tanycythere.

\section{Tanycythere $\mathrm{sp} .1$}

(Fig. 6:6-8)

Material. Two adult carapaces: samples $\mathrm{P}(-4 \mathrm{~T}), \mathrm{P}(4 \mathrm{M})$.

Description. Elongate, characteristically spindle-shaped; small size; valves of very similar size; greatest length at mid-height, greatest height just anterior of mid-length, greatest width at mid-length. Dorsal margin straight merging into the broadly rounded anterior margin, ventral margin weakly convex, posterior margin extended and pointed and merges with ventral margin, whereas there is a clear posterior cardinal angle where it joins the dorsal margin. Surface ornamented with fine longitudinal striae. Internal features unknown.

Dimensions. $\mathrm{L}: \mathrm{P}(-4 \mathrm{~T})=0.600, \mathrm{P}(4 \mathrm{M})=0.575 ; \mathrm{H}: \mathrm{P}(-4 \mathrm{~T})=$ $0.200, \mathrm{P}(4 \mathrm{M})=0.225$.

Occurrence. Athleta Zone, Upper Callovian, Pedrógão (this work).

Remarks. This is a new species of Tanycythere but more material is required for formal description. The two specimens figured may represent two different species.

\section{Family Schulerideidae Mandelstam, 1959}

Genus Praeschuleridea Bate, 1963

Type species Cytheridea subtrigona Jones \& Sherborn, 1888

\section{Praeschuleridea lisensis sp. nov. Pais, Cabral \& Lord} (Fig. 6:9-16)

Etymology. From the River Lis adjacent to the sample site.

Diagnosis. A species of Praeschuleridea characterized by a subtriangular to suboval outline, position of greatest length in ventral half of valves, strong left valve larger than right valve overlap especially on the dorsal and ventral margins, surface smooth and unornamented.

Types. Holotype: 9 C, SMF Xe 23204, Figure 6:13. Paratypes: ㅇ LV, SMF Xe 23201, Figure 6:9; đ LV, SMF Xe 23202, Figure 6:10; o LV, SMF Xe 23203, Figure 6:11, 12; ㅇ C, SMF Xe 23205, Figure 6:14; ㅇ LV, SMF Xe 23206, Figure 6:15; đo RV, SMF Xe 23207, Figure 6:16.

Material. 1920 specimens - adults and juveniles, valves and carapaces: samples $\mathrm{P}(-8), \mathrm{P}(-6 \mathrm{~B}), \mathrm{P}(--\mathrm{T}), \mathrm{P}(-4 \mathrm{~B}), \mathrm{P}(-4 \mathrm{~T}), \mathrm{P}(-2)$, $\mathrm{P}(0), \mathrm{P}(2 \mathrm{~B}), \mathrm{P}(2 \mathrm{M}), \mathrm{P}(4 \mathrm{M}), \mathrm{P}(6)$.
Description. Subtriangular to suboval outline, medium size; LV > RV but valves are asymmetrical with LV strongly overlapping RV especially along the dorsal and ventral margins, LV more rounded than RV especially in o; greatest length just ventral of mid-height, greatest height at or just anterior of mid-length, greatest width at mid-length. All margins convex, the anterior more symmetrically rounded than the posterior. Valve surface smooth and unornamented with a few depressions at normal pore canals. Sexual dimorphism pronounced with $\sigma^{\star}$ more elongate than the relatively rounded $\%$. Internally hinge palaeohemimerodont typical for genus with, in LV, strong terminal loculate sockets joined by a groove along a short, smooth median bar, above which an accommodation groove is present (Fig. 6:11,15), complementary structures in RV; muscle scars consist of four rounded adductor scars and a rounded frontal scar (Fig. 6:12; 'Type C' of Bate 1963, p. 182); marginal zone well developed, inner margin and line of concresence coincide, radial pore canals straight, approximately 12 anteriorly and 6 posteriorly.

Dimensions. of $\mathrm{L}=0.500-0.600, \mathrm{H}=0.250-0.300$. 우 $\mathrm{L}=0.375$ $0.500, \mathrm{H}=0.275-0.375$.

Occurrence. Athleta Zone, Upper Callovian, Pedrógão (this work).

Remarks. Many described species of Praeschuleridea are strongly ornamented with ribs or punctae whereas $P$. lisensis sp. nov. is smooth. Praeschuleridea confossa Sheppard, 1981 from the Bathonian of England (Sheppard 1981) and lower Callovian of France (Dépêche 1985) is similar to P. lisensis sp. nov. but has a more uniformly rounded outline and relatively weak and uniform LV > RV overlap; it may well be ancestral to lisensis. Praeschuleridea subtrigona (Jones \& Sherborn, 1888) from the Bajocian-Bathonian of England (Bate 2009) differs from the Portuguese species in having a more triangular carapace with RV more elongate than LV and is more acuminate posteriorly. Mette (1995) figures two species of Praeschuleridea, $P$. sp. 1 and $P$. sp. 2, from the Callovian of Tunisia which, like $P$. lisensis sp. nov. are unornamented but differ in shape and appear to have marginal rims and eye tubercles more typical of the genus Schuleridea Swartz \& Swain; furthermore, it is not clear if they have the palaeohemimerodont hingement characteristic of Praeschuleridea.

Family Protocytheridae Ljubimova, 1955

Genus Palaeocytheridea Mandelstam, 1947

Type species. Palaeocytheridea (Palaeocytheridea) bakirovi Mandelstam, 1947.

Remarks. Numerous species were assigned to Palaeocytheridea by workers in the former Soviet Union and the taxonomy is confused. Tesakova (2013a, b, c, 2014) has substantially revised the genus. At present the species from Western Europe formally placed in this genus are P. (Malzevia) blaszykina Franz et al., 2009 [BajocianBathonian; France, Germany, Poland], P. (P.) carinilia (SylvesterBradley, 1948) [Bathonian; England, France, south Germany], $P$. (M.) parabakirovi Malz, 1962 [Bathonian; England, The Netherlands, Germany - Malz 1962; Callovian; Ukraine, central Russia] and. P. (Malzevia) groissi Schudack, 1997 [Tithonian; south Germany - Schudack 1997].

Palaeocytheridea (Malzevia)? dorsocostata sp. nov. Cabral, Pais \& Lord

(Fig. 6:17-18, Fig. 7:1-5) 
Etymology. From the dorsal costate ridge.

Diagnosis. A species of Palaeocytheridea (Malzevia)? characterized by a dorsal blade-like costate ridge on LV, a weak, short and curved ventral rib below a longer ventral rib, two weak oblique central ribs, an eye tubercle with a weak rib below, and secondary reticulation.

Types. Holotype: $q$ C, SMF Xe 23208, Figure 6:17, Figure 7:4. Paratypes: o LV, SMF Xe 23209, Figure 6:18; ㅇ LV, SMF Xe 23210, Figure 7:1; đ RV, SMF Xe 23211, Figure 7:2; đ RV, SMF Xe 23212, Figure 7:3; ᄋ C, SMF Xe 23213, Figure 7:5.

Material. 30 specimens - adults and juveniles, valves and carapaces: sample $\mathrm{P}(6)$, and same bed as sample $\mathrm{P}(6)$ of this work, sampled laterally (1998).

Description. Subrectangular tapered outline, small size; LV $>$ RV; greatest length at mid-height, greatest height at anterior cardinal angle, greatest width just posterior of mid-length. Dorsal margin slightly convex and on LV formed by a blade-like costate ridge ornamented with short weak vertical ribs, anterior margin asymmetrically rounded, posterior margin triangular with extremity at mid-height. Eye tubercle present, ornamented with a short weak vertical rib. In addition to the dorsal marginal LV rib, there is a weak and curved rib running parallel and close to the ventral margin with a longer rib just above it terminating obliquely at the anterior margin; and two oblique curved ribs in the anterior and mid-dorsal areas; secondary reticulation present. Sexual dimorphism present, males differ in L:H ratio and generally appear more elongate than females. Internally, hingement is antimerodont, inner margin coincides with line of concresence; details of muscle scars and radial pore canals not seen.

Dimensions. $\widehat{\sigma} \mathrm{L}=0.425-0.450, \mathrm{H}=0.225$. 우 $\mathrm{L}=0.350-0.450$, $\mathrm{H}=0.200-0.250$.

Occurrence. Athleta Zone, Upper Callovian, Pedrógão (this work).

Remarks. Palaeocytheridea (M.)? dorsocostata sp. nov. is similar to P. (M.) blaszykina (Franz et al. 2009, pl. 2, figs 15-18) described from the Bathonian of SW Germany. Our material is especially close in shape and size to the juvenile figured by Franz et al. in their plate 2, fig. 18. However, our material is adult and differs from $P$. (M.) blaszykina in the configuration of the primary ornament in the main valve area. A number of species of Palaeocytheridea figured by Tesakova $(2013 a, b)$ resemble dorsocostata sp. nov., especially in the presence of the LV dorsal marginal blade-like ridge; however, all differ in strength and arrangement of the primary ribbing and secondary ornament.

\section{Family Cytherideidae Sars, 1925}

Genus Virgulacytheridea Oertli \& Dépêche, 1987 in Dépêche et al. (1987)

Type species. Virgulacytheridea sherifensis Oertli \& Dépêche, 1987 in Dépêche et al. (1987).

Remarks. The name Virgulacytheridea was first published in Maync (1966) as a nomen nudum in a list of ostracods ascribed to H. J. Oertli from the Jurassic (Lower to Middle Bathonian) of Israel. One new species was recognized as Virgulacytheridea sherifensis n. gen., n. sp. Oertli (nomen nudum) (Maync 1966, 13). The species was illustrated (Maync 1966, pl. X, figs 49-54) but figs 49-51 are clearly different from figs $52-54$ and probably represent two different species; the figures are apparently of single specimens viewed from left, right and dorsally. Subsequently Oertli \& Dépêche (in Dépêche et al. 1987) described and figured $V$. sherifensis from the Middle Callovian of Saudi Arabia and designated types (holotype FDO 75, paratypes FDO 76). Virgulacytheridea sherifensis of Oertli \& Dépêche (in Dépêche et al. 1987) is different from the two forms figured in Maync (1966) which represent two other, undescribed, species of Virgulacytheridea. We have tried to locate the original material of Maync (1966) in Israel (Geological Survey of Israel and elsewhere) and in the Oertli Ostracod Collection, Muséum d'Histoire Naturelle, Genève without success.

Virgulacytheridea has been recognized in Portugal and identified as $V$. aff. $V$. sherifensis Oertli \& Dépêche (Cabral et al. 1998, 2003) from two different localities, Pedrógão and a borehole at Vermoil. During the present work we have found many more specimens from Pedrógão and conclude that Virgulacytheridea Oertli \& Dépêche, 1987 is a valid Middle Jurassic genus of Tethyan affinities represented by at least four species.

$$
\begin{aligned}
& \text { Virgulacytheridea posteroacuminata sp. nov. Cabral, Lord \& } \\
& \text { Pais } \\
& \text { (Fig. } 7: 12-19)
\end{aligned}
$$

Etymology. A reference to the pointed, ventrally inclined posterior margin.

Diagnosis. A species of Virgulacytheridea characterized by elongate carapace with a pointed, ventrally inclined posterior margin, with a subtle ornament of two fine ribs preserved in the postero-ventral area and a small ventrally-directed posterior spine.

Types. Holotype: $₫$ RV, SMF Xe 23224, Figure 7:16. Paratypes: $\delta$ C, SMF Xe 23220, Figure 7:12; đo C, SMF Xe 23221, Figure 7:13; 우 LV, SMF Xe 23222, Figure 7:14; ㅇ RV, SMF Xe 23223, Figure 7:15; đ LV, SMF Xe 23225, Figure 7:17; đ RV, SMF Xe 23226, Figure 7:18; ㅇ LV, SMF Xe 23227, Figure 7:19.

Material. 175 specimens - adults, valves and carapaces: samples $P$ (2M), $\mathrm{P}(4 \mathrm{M}), \mathrm{P}(6)$.

Description. Outline in shape of a comma, medium size; LV > RV; greatest length just dorsal of ventral margin, greatest height at onethird of length from anterior, greatest width at mid-length. Dorsal margin convex sloping steeply towards posterior, anterior margin broadly and symmetrically rounded, ventral margin convex but with concave incurve posteriorly, posterior margin short and low on valve with a ventrally-directed spine. $\delta^{t}$ more elongate than $\$$ which are shorter and more rounded. Valve surface almost smooth, in better preserved specimens two very weak postero-ventral ribs run from the mid-ventral area to the posterior extremity; these weak ribs can also be seen in ventral view. Internally hinge antimerodont, marginal zone broad and inner margin coincides with line of concrescence; details of muscle scars and radial pore canals not observed.

Dimensions. $\sigma^{\top} \mathrm{L}=0.475-0.575, \mathrm{H}=0.225-0.275$. $\quad \mathrm{OL}=0.425$ $0.500, \mathrm{H}=0.225-0.275$.

Occurrence. Upper Callovian, Vermoil (Cabral et al. 2003); athleta Zone, Upper Callovian, Pedrógão (this work).

Remarks. Virgulacytheridea sherifensis has a punctate surface ornament and is less elongate than the smooth $V$. posteroacuminata sp. nov. As a consequence of the different L:H ratio, sherifensis is more hooked posteriorly than posteroacuminata. Maync's (1966) 


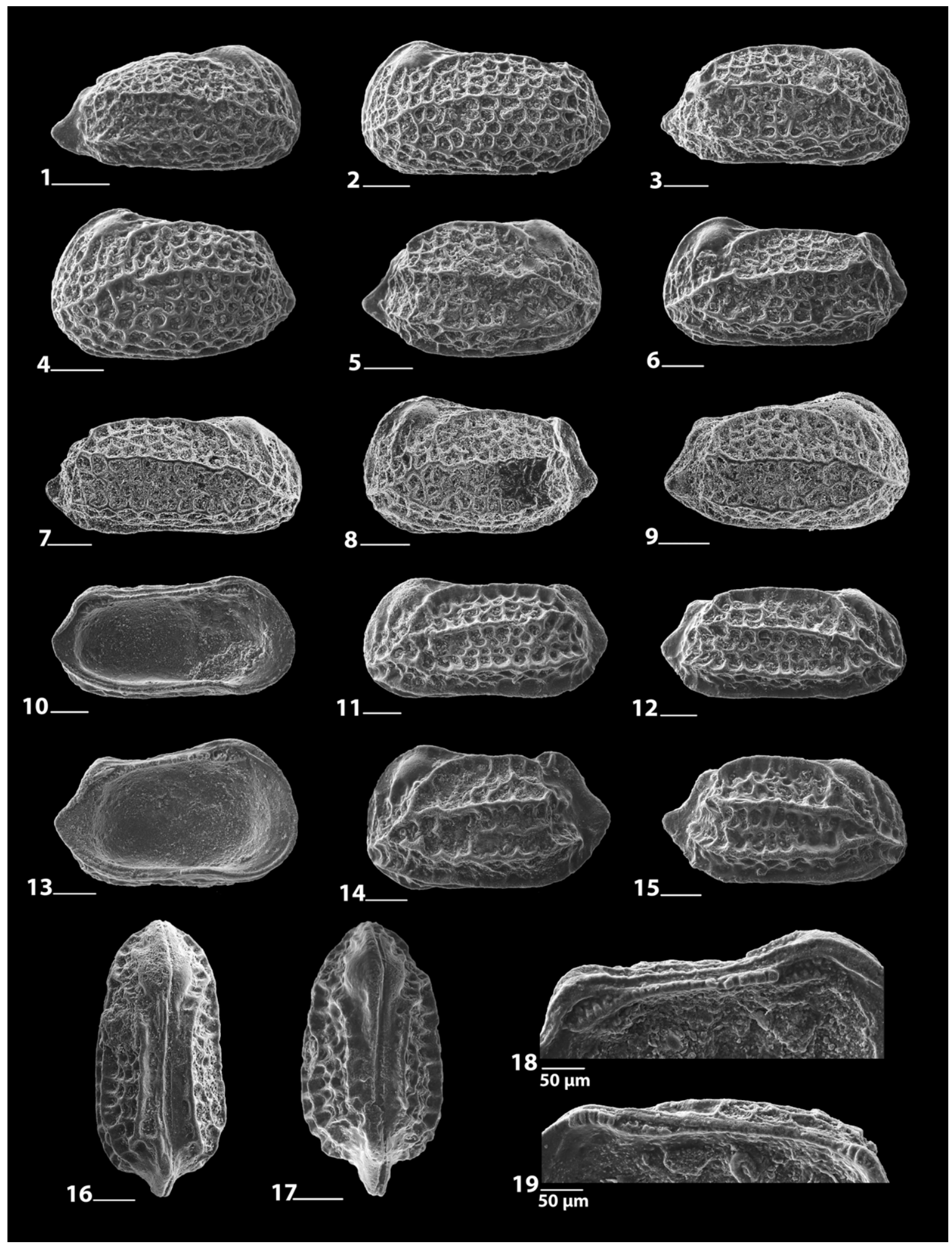

Fig. 8. (1-19) Neurocythere multiforma sp. nov. Pais, Lord \& Cabral. 1. RV, external, juv., paratype, SMF Xe 23230, P(6), Upper Callovian, Pedrógão, Portugal, $\mathrm{L}=0.40, \mathrm{H}=0.20$. (2-4) Morphotype III: 2, ô LV, external, paratype, SMF Xe 23231, P(-2), Upper Callovian, Pedrógão; Portugal, L=0.525, $\mathrm{H}=0.250 ; 3$, o RV, external, paratype, SMF Xe 23232, P(-4)T, Upper Callovian, Pedrógão, Portugal, L = 0.550, H = 0.274; 4, ᄋ LV, external, paratype, SMF Xe 23233 P(-2), Upper Callovian, Pedrógão, Portugal, L =0.450, H = 0.274. (5-9) Morphotype II: 5, ᄋ RV, external, paratype, SMF Xe 23234, $\mathrm{P}(-2)$, Upper Callovian, Pedrógão, Portugal, $\mathrm{L}=0.476, \mathrm{H}=0.274 ; \mathbf{6}$, đ LV, external, paratype, SMF Xe 23235, $\mathrm{P}(6)$, Upper Callovian, Pedrógão, Portugal, $\mathrm{L}=0.550, \mathrm{H}=0.250 ; 7$, o $\mathrm{RV}$, external, paratype, SMF Xe 23236, $\mathrm{P}(6)$, Upper Callovian, Pedrógão, Portugal, L = 0.575, H = 0.274; 8, ㅇ LV, external, paratype, SMF Xe 23237, P(6), Upper Callovian, Pedrógão, Portugal, L = 476, H=0.274; 9, q C, right view, external, paratype, SMF Xe 23238, $\mathrm{P}(6)$, Upper Callovian, Pedrógão, Portugal, $\mathrm{L}=0.476, \mathrm{H}=0.274$. (10-19) Morphotype I: 10, đ̊ LV, internal, paratype, SMF Xe 23239, P(-2), Upper Callovian, Pedrógão, Portugal, $\mathrm{L}=0.525, \mathrm{H}=0.274 ; 11$, o LV, external, paratype, SMF Xe 23240, $\mathrm{P}(0)$, Upper Callovian, Pedrógão, Portugal, $\mathrm{L}=0.624, \mathrm{H}=0.3 ; 12$, ơ RV, external, paratype, SMF Xe 23241, P(0), Upper Callovian, Pedrógão, Portugal, L =0.650, H=0.3; 13, LV, internal, paratype, SMF Xe 23242, $\mathrm{P}(0)$, Upper Callovian, Pedrógão, Portugal, L = 0.550, H=0.350; 14, ᄋ LV, external, holotype, SMF Xe 23243, P(-8), Upper Callovian, Pedrógão, Portugal,

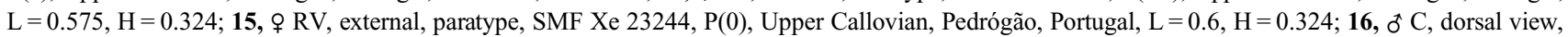
paratype, SMF Xe 23245, P(4M), Upper Callovian, Pedrógão, Portugal, L = 0.675, H=0.350; 17, o C, dorsal view, paratype, SMF Xe 23246, $\mathrm{P}(0)$, Upper Callovian, Pedrógão, $\mathrm{L}=0.550, \mathrm{H}=0.324 ; 18$, o LV, internal, hinge detail, paratype, SMF Xe 23247, $\mathrm{P}(-2)$, Upper Callovian, Pedrógão, $\mathrm{L}=0.5, \mathrm{H}=0.324 ; 19$, ㅇ RV, internal, hinge detail, paratype, SMF Xe 23248, $\mathrm{P}(6)$, Upper Callovian, Pedrógão, $\mathrm{L}=0.525, \mathrm{H}=0.3$. Scale bars $100 \mu \mathrm{m}$ except where otherwise noted. 


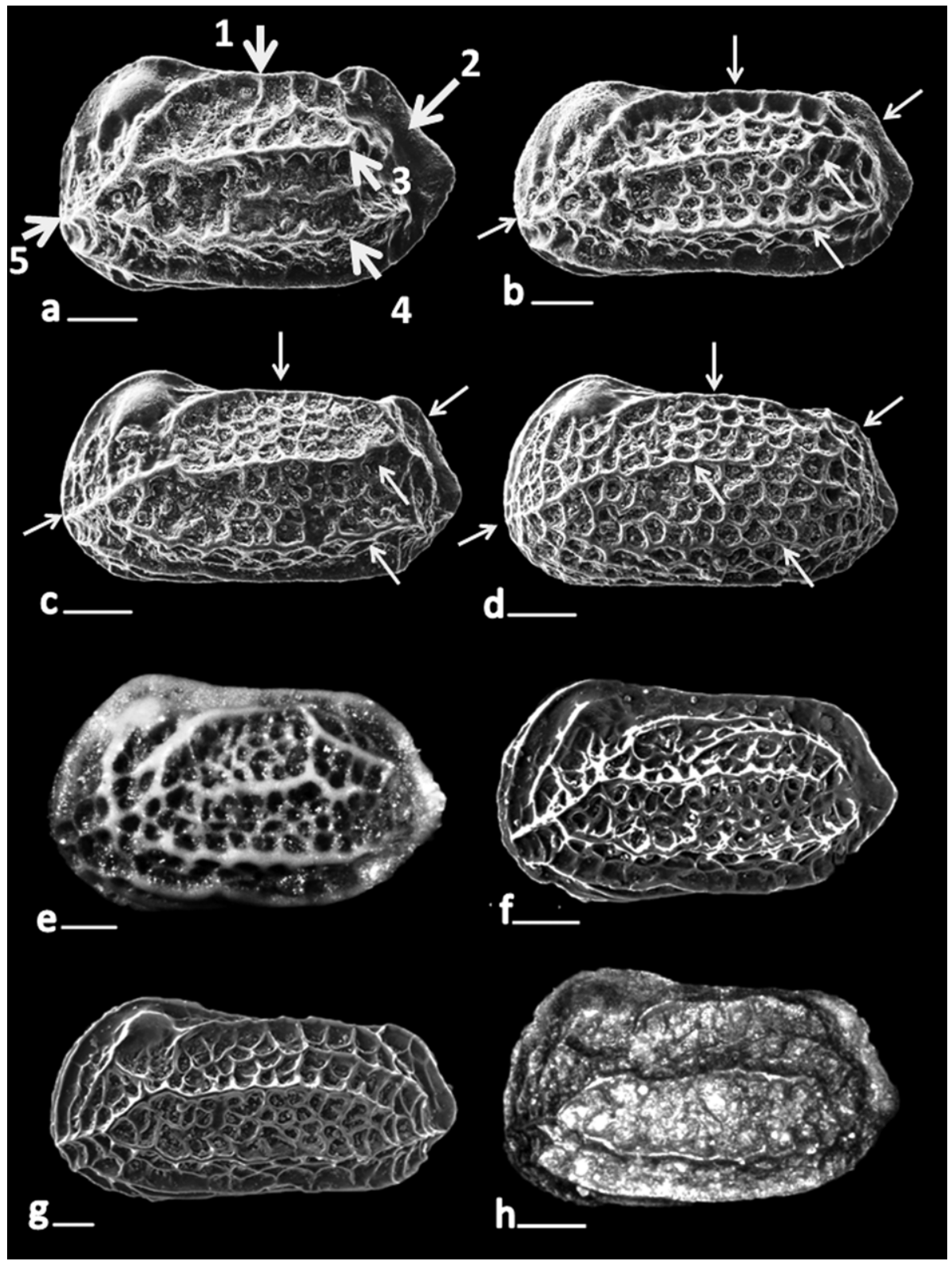

Fig. 9. Neurocythere multiforma sp. nov.: (a) Morphotype I (holotype, SMF Xe

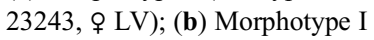
(paratype, SMF Xe 23240, ơ LV); (c) Morphotype II (paratype, SMF Xe 23235, o LV) ; (d) Morphotype III (paratype, SMF Xe 23231, ơ LV); (e) Lophocythere caesa Triebel, 1951 ( = Neurocythere caesa caesa (Triebel, 1959)) (holotype, SMF Xe 1799, LV). (f) Neurocythere caesa subspecies A of Wilkinson \&

Whatley (2009, pl. 7. fig. 15; HU.19.J.60, LV gender uncertain). (g) Neurocythere caesa caesa (Triebel, 1951) of Wilkinson \& Whatley (2009, pl. 7. fig. 14; HU.19. J.53, ơ LV). (h) Neurocythere composita (Wienholz, 1967) (holotype, X1983, C). Scale bars $100 \mu \mathrm{m}$. (e) Light micrograph with Helicon Focus and Leica S8 APO microscope. (h) Light micrograph with Keyence Digital Microscope VHX-100D. All other images SEM.

poor figures of Virgulacytheridea from Israel appear to show two species: Type 1 (Maync 1966, pl. 10, figs 49-51) is smooth but has a different L:H:W ratio to posteroacuminata; Type 2 (Maync 1966, pl. 10, figs 52-54) has a sinuous dorsal margin with a narrow width, may be ornamented and differs from both sherifensis and posteroacuminata sp. nov.

\section{Family Progonocytheridae Sylvester-Bradley, 1948}

Genus Micropneumatocythere Bate, 1963

Type species. Micropneumatocythere convexa Bate, 1963

\section{Micropneumatocythere sp. 1}

$$
\text { (Fig. 7:6-7) }
$$

Material. Nine specimens - adults, valves and carapaces: samples $\mathrm{P}(-2), \mathrm{P}(6)$.

Description. Subtriangular outline, small size; $L V>R V$; greatest length at mid-height, greatest height and width at approximately mid-length. Dorsal margin weakly convex and inclined steeply towards posterior, posterior margin triangular at mid-height, anterior margin rounded, ventral margiun convex but hidden in lateral view by a strong ventral inflation. Valve surface smooth and unornamented other than ventral ridges under the ventral inflation. Sexual dimorphism not observed, material appears to be juvenile. Internally hinge antimerodont, as described for adults of the genus, inner margin and line of concrescence coincide, other features not seen.

Dimensions. $\mathrm{L}=0.375-0.450, \mathrm{H}=0.200-0.250$.

Occurrence. Athleta Zone, Upper Callovian, Pedrógão (this work).

Remarks. The posterior margin of our material is not typical for Micropneumatocythere, in which it tends to be extended and slightly upturned (see Bate \& Sheppard 1979), and we have made the assignment to the genus on the basis of the ventral inflation and antimerodont hingement. Many species have been assigned to Micropneumatocythere (Bate \& Sheppard 1979). Micropneumatocythere globosa Bate, 1964 from the Bajocian (Bate 1964) is smooth to finely punctate but has a more rounded outline especially of the larger LV; M. quadrata Bate, 1967 is also smooth but has a more rounded outline especially in $\$ \mathrm{LV}$ 


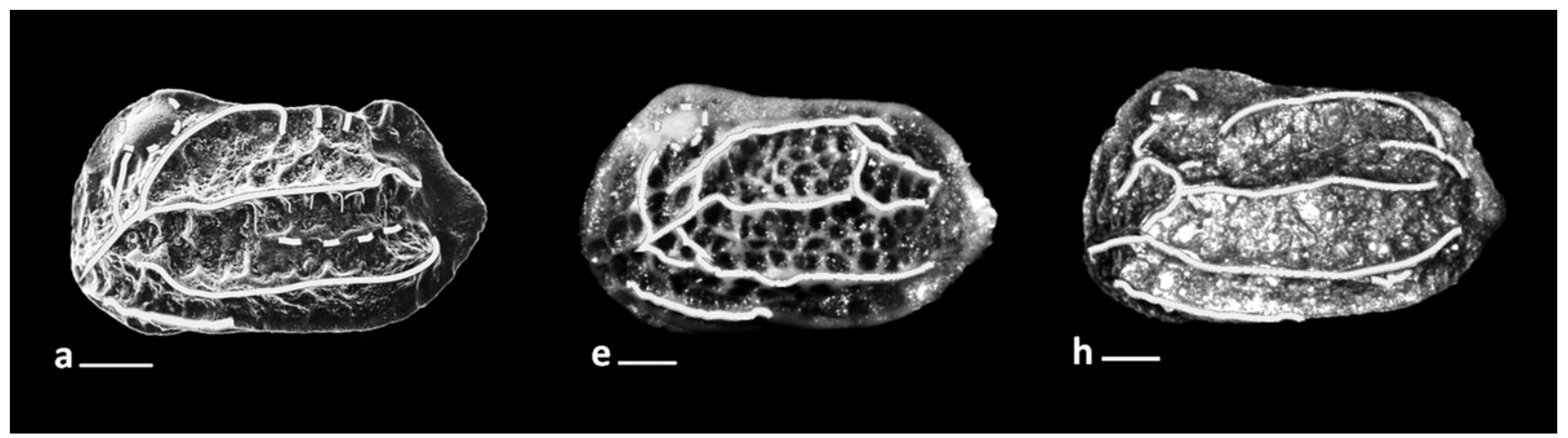

Fig. 10. Comparison of primary ornament of (a) Neurocythere multiforma sp. nov., Morphotype I (holotype, SMF Xe 23243, o LV). (e) Neurocythere caesa caesa (Triebel, 1951) (holotype, SMF Xe 1799, o LV). (h) Neurocythere composita (Wienholz, 1967) (holotype, X1983, o C). Images from Figure 9, all left lateral views. Scale bars $100 \mu \mathrm{m}$.

(Bathonian, Bate 1967). Micropneumatocythere laevireticulata Rosenfeld \& Honigstein, 1991 is slightly larger and has surface ornamentation.

Gen. nov.?

Remarks. Bizon (1958) placed his new species gublerae in Progonocythere? and his drawing (1958, pl. 4, fig. 16) indicates a four-part entomodont hinge (the median groove is clearly larger anteriorly) which at that time and with entomodont hingement made assignment to the genus Progonocythere Sylvester-Bradley, 1948 reasonable. However, a more clearly defined definition of that genus based on the type species P. stilla Sylvester-Bradley, 1948 (see Whatley \& Ballent 1996, 921, and cf. Sylvester-Bradley 1948) and recognition that most but not all records of gublerae have a three-part merodont hinge has confused the generic placement. Subsequent authors (see synonymy list below) have mostly placed the species in Procytheridea Peterson. ARL considers Procytheridea to be represented by only two species, P. exempla Peterson, 1954 and $P$. fraudator Sherrington \& Lord, 1975b, and to be restricted in distribution to North America (Peterson 1954; Lord 1972; Sherrington \& Lord $1975 a, b$ ) although there is some similarity in external shape and hingement to gublerae. The question of a generic assignment for gublerae remains open as the present authors have been unable to recognize an appropriate described genus in the literature.

Gen. nov.? gublerae (Bizon, 1958)

$$
\text { (Fig. 7:8-11) }
$$

1958 Progonocythere? gublerae Bizon: 28, pl. 4, figs 14-16. 1959 Procytheridea gublerae (Bizon, 1958); Oertli: 38 -39, pl. 6, figs 172-177, pl. 7, figs 178-180.

1962 Procytheridea gublerae Bizon, 1958; Donze: 139, pl. 11, figs 48-49.

?1964 Procytheridea gublerae (Bizon, 1958); Glashoff: 47.

1966 Procytheridea aff. gublerae Bizon; Oertli in Maync: 13, pl. 10, figs 55-57.

1985 Procytheridea gublerae Bizon, 1959; Dépêche: pl. 32, figs $16-18$

1987 a Terquemula gublerae (Bizon, 1958); Rosenfeld et al:: 243, pl. 3, figs 9-10.

1987b Terquemula gublerae (Bizon, 1958); Rosenfeld et al.: 261, pl. 6, fig. 4 .

2000 Procytheridea gublerae Bizon, 1958; Schudack \& Schudack: pl. 4, figs 4,5 .

2001 'Procytheridea' gublerae (Bizon, 1958); Olempska \& Błaszyk: $560-561$, fig. $4 \mathrm{a}-\mathrm{i}$.
2009 'Procytheridea' gublerae (Bizon, 1958); Franz et al:: 138, pl. 3, fig. 5 .

Material. 50 specimens - adults and juveniles, valves and carapaces: samples $\mathrm{P}(2 \mathrm{~B})$. $\mathrm{P}(2 \mathrm{M}), \mathrm{P}(4 \mathrm{M}), \mathrm{P}(6)$.

Description. Subtriangular outline, medium size; LV $>$ RV; greatest length just below mid-valve height, greatest height just anterior of mid-length, greatest width at mid-length. Dorsal margin slightly convex and inclined steeply towards posterior, posterior margin low and triangular, ventral margin convex, anterior margin evenly rounded; anterior and posterior cardinal angles evident. Marked anterior marginal rim. A swelling just below the anterior cardinal angle in LV or adjacent in RV may be an eye tubercle. Sexual dimorphism not observed. In well-preserved material (e.g. Olempska \& Błaszyk 2001, figs 4a, f) the primary ornament consists of a roughly triangular network linked by weaker secondary ribs creating a background reticulate network; in the smaller RV the apex of the primaray rib triangle reaches the dorsal margin; instars appear punctate. Internally hingement is antimerodont, marginal zone well developed and inner margin coincides with line of concrescence; details of muscle scars and radial pore canals not observed.

Dimensions. L (adults) $=0.500-0.625, \mathrm{H}=0.325-0.375$. L (juveniles $)=0.350-0.475, \mathrm{H}=0.225-0.300$.

Occurrence. Widely recorded in the Callovian-Oxfordian of Western and Central Europe (see synonymy); the records from Israel (Oertli in Maync 1966) and adjacent areas (Rosenfeld et al. $1987 a, b)$ are convincing. Athleta Zone, Upper Callovian, Pedrógão (this work)

Remarks. Published figures show some variation in ornament but this appears to be taphonomic rather than original variation.

Genus Neurocythere Whatley, 1970

Type species. Cythere bradiana Jones, 1884.

Remarks. Whatley \& Ballent (2004) have made a helpful revision of Lophocythere and related genera including Neurocythere which provides an insight into the tortuous taxonomic history of these animals.

Neurocythere multiforma sp. nov. Pais, Lord \& Cabral (Fig. 8:1-19, Figs 9 and 10) 
Etymology. An allusion to the systematic variation in primary and secondary ornament.

Diagnosis. A quadrate species of Neurocythere with a primary ornament of three longitudinal ribs and secondary reticulation, the relative strengths of which are variable between three morphotypes.

Types. Holotype: $९$ LV, SMF Xe 23243, Figure 8:14. Paratypes: juv

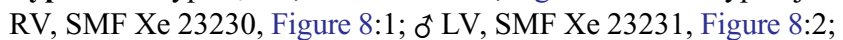
o RV, SMF Xe 23232, Figure 8:3; ㅇ LV, SMF Xe 23233, Figure 8:4; ㅇ RV, SMF Xe 23234, Figure 8:5; đત LV, SMF Xe 23235, Figure 8:6; o RV, SMF Xe 23236, Figure 8:7; ㅇ LV, SMF Xe 23237, Figure 8:8; ᄋ C, SMF Xe 23238, Figure 8:9; đ̊ LV, SMF Xe 23239, Figure 8:10; ${ }^{\star}$ LV, SMF Xe 23240, Figure 8:11; ${ }^{\star} \mathrm{RV}$, SMF Xe 23241, Figure 8:12; ㅇ LV, SMF Xe 23242, Figure 8:13; ㅇ RV, SMF Xe 23244, Figure 8:15; ð C, SMF Xe 23245, Figure 8:16; ㅇ C, SMF Xe 23246, Figure 8:17; ᄋ LV, SMF Xe 23247, Figure 8:18; ㅇ RV, SMF Xe 23248, Figure 8:19.

Material. 710 specimens - adults and juveniles, valves and carapaces: samples $\mathrm{P}(-8), \mathrm{P}(-6 \mathrm{~B}), \mathrm{P}(-6 \mathrm{~T}), \mathrm{P}(-4 \mathrm{~B}), \mathrm{P}(-4 \mathrm{~T})$, $\mathrm{P}(-2), \mathrm{P}(0), \mathrm{P}(2 \mathrm{~B}), \mathrm{P}(2 \mathrm{M}), \mathrm{P}(4 \mathrm{M}), \mathrm{P}(6)$.

Description. Quadrate outline especially in females; juveniles taper posteriorly. Greatest length at or just below mid-height, greatest height at anterior in LV but mid-length in RV, greatest width in posterior third of length in both $\$$ and $\delta^{t}$. Anterior margin broadly rounded, ventral margin straight to weakly concave, posterior margin a low triangular rim. Dorsal margin variable posterior of anterior cardinal angle and eye tubercle: LV dorsal margin straight to slightly concave, RV convex with margin in lateral view formed by the dorsalmost rib. Based on shape and surface ornament, three morphotypes are recognized, all with adults $(\stackrel{+}{\diamond)}$ :

Morphotype I (Fig. 8:10-19): primary ornament of three strong, blade-like ribs, one forming the dorsal margin and running anteriorly below the eye tubercle to join the median rib at anterior, a median rib running diagonally from postero-dorsal area to anteroventral margin, and a third rib running parallel to but above the ventral margin and meeting the median rib anteriorly; secondary reticulate ornament. Posterior marginal rim strong, especially in + and extends to dorsal margin where it forms the posterior cardinal angle as a bladed extension. Eye tubercles present in all three morphotypes, with a weak ventral rib.

Morphotype II (Fig. 8:5-9): primary ornament as in I but difference in relative strengths of primary ribs and secondary reticulation less marked; postero-dorsal extension recognizable but weaker.

Morphotype III (Fig. 8:2-4): primary ornament of three ribs recognizable but only slightly more strongly developed than the 'secondary' reticulation; posterior margin triangular but no longer a strong rim (although this is seen in juveniles, Fig. 8:1). The relative strengths of primary and secondary ornament in Morphotypes II and III are clear in the SEM but less obvious in reflected light microscopy. From relative dimensions, Morphotype III might appear to be the A-1 instar of Morphotype II; however, internally the hingement and marginal zone are adult.

Juveniles (A-1 and smaller; Fig. 8:1) are closest in surface ornament to Morphotype III, demonstrating that the morphological variation (I to III) is an adult phenomenon in one species. The juvenile instars cannot be differentiated into the three morphotypes.

The ornamental development of the three morphotypes is compared in Figure 9. Figure 9a is Morphotype I (\%) where arrow 1 indicates the dorsal primary rib, arrow 2 the posterior rim and blade-like posterodorsal extension, arrow 3 the diagonal median rib and weak connection to the dorsal rib posteriorly, arrow 4 is the ventral primary rib and arrow 5 marks where the three primary ribs are joined and reach the antero-ventral margin. Figure $9 \mathrm{~b}$ is Morphotype I ( $\left.\sigma^{\star}\right)$. Figure $9 \mathrm{c}$ is Morphotype II ( $\left.\sigma^{*}\right)$ and Figure $9 \mathrm{~d}$ is Morphotype III $\left({ }^{\star}\right)$ - arrows indicate comparison with Morphotype I. Figure $9 \mathrm{e}-\mathrm{h}$ are discussed under Remarks.

Sexual dimorphism recognized in all three morphotypes based on $\mathrm{L}: \mathrm{H}$ ratio and posterior inflation, ơ being relatively longer than $\$$.

Internally all morphotypes are the same: marginal zone relatively wide, inner margin coincides with line of concresence. Marginal pore canals difficult to observe because of recrystallization but appear short and straight. Muscle scars consist of four rounded adductor scars with a round frontal scar typical of the genus. Hingement entomodont, strongly developed, with in LV loculate sockets anteriorly and posteriorly and a median dentate ridge more strongly developed anteriorly, complementary structures in RV (Fig. 8:18-19).

\section{Dimensions.}

o L: Morphotype I $=0.525-0.750$, Morphotype $\mathrm{II}=0.525-0.600$, Morphotype III $=0.500-0.525 ; \mathrm{H}: \mathrm{I}=0.300-0.325, \mathrm{II}=0.275-$ $0.325, \mathrm{III}=0.250-0.275$.

ㅇ L: $\mathrm{I}=0.550-0.625, \mathrm{II}=0.475-0.525, \mathrm{III}=0.425-0.500 ; \mathrm{H}$ : $\mathrm{I}=0.275-0.374, \mathrm{II}=0.250-0.300, \mathrm{III}=0.225-0.275$.

Juveniles $\mathrm{L}=0.375-0.425, \mathrm{H}=0.200-0.250$.

Occurrence. Athleta Zone, Upper Callovian, Pedrógão (this work).

Remarks. When first assessing this material we considered several options, that it represents:

1. three species, each with sexually dimorphic adults plus juveniles; however, all occur together in 11 stratigraphically sequential samples, all share the same internal features and basic ornamental pattern and juveniles cannot be differentiated;

2. three subspecies; however, there is no stratigraphical or geographical separation to justify subspecific distinction and the 'species' is, as yet, not known elsewhere;

3. three 'varieties' of one species - the model adopted here with Morphotypes I to III, supported by the fact that the juveniles are all the same.

Neurocythere multiforma sp. nov. is represented by over 700 specimens with adults and juveniles occurring in $9 \mathrm{~m}$ of sediment. It is difficult to accurately assess the time represented by $9 \mathrm{~m}$ of marllimestone deposition in the absence of good time markers, but comparison with comparable depositional environments suggests a rate of deposition of the order of $c .5 \mathrm{~cm} \mathrm{ka}^{-1}$, i.e. a maximum of $180 \mathrm{ka}$, although allowing for compaction of the sediments the time represented could be at least double, i.e. $360-400 \mathrm{ka}$. (Note that the species is present in the oldest sampled horizon and ranges through the marine part of the section, its occurrence at Pedrógão truncated by the onset of non-marine conditions, thus its actual time range is longer than represented by our samples.) These individuals appear to represent contemporaneous interbreeding populations over an extended period of time, if the carapace characteristics reflect genuine biological species. It is possible that in life they were separated by niche-partitioning and their co-occurrence in the samples is a taphonomic phenomenon; however, given the time span represented by the samples this seems unlikely. See Discussion below.

Given the number of Neurocythere species recognized (Whatley \& Ballent 2004, 97-101, list almost 40 species and subspecies), it seems unlikely that our material is new. However, inspection of the literature and of type and comparative material from Berlin, Frankfurt and London shows that no described taxon is an exact match in terms of specific characteristics of ornament and valve shape. Figure 9 compares multiforma sp. nov. (a-d) with the holotype of Neurocythere caesa (Triebel, 1951) (e), N. caesa subsp. A of Wilkinson \& Whatley (2009) (f), N. caesa caesa (Triebel, 1951) in 


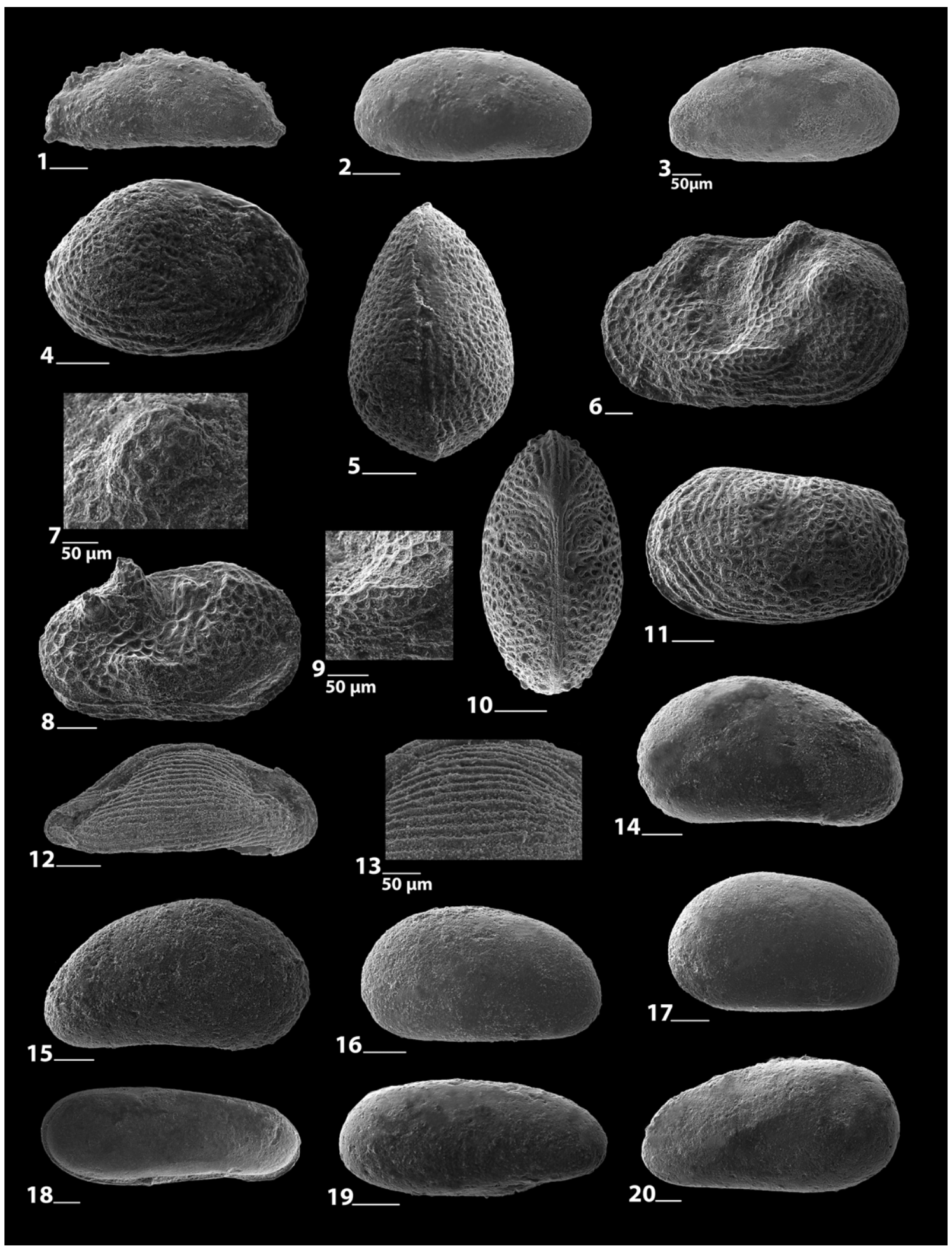

Fig. 11. (1) Genus and species indeterminate 1: C, left view, external, SMF Xe 23249, $\mathrm{P}(-8)$, Upper Callovian, Pedrógão, Portugal, $\mathrm{L}=0.624, \mathrm{H}=0.250$ $(\mathbf{2}, \mathbf{3})$ Genus and species indeterminate 3: 2, C, left view, external, SMF Xe 23250, $\mathrm{P}(0)$, Upper Callovian, Pedrógão, Portugal, $\mathrm{L}=0.5, \mathrm{H}=0.225 ; \mathbf{3}, \mathrm{C}$, right view, external, SMF Xe 23251, P(-2), Upper Callovian, Pedrógão, Portugal, L =0.425, H=0.2. (4, 5) Sinuocythere pedrogaensis Cabral \& Colin, 2000 in Colin et al. (2000): 4, q RV, external, SMF Xe 23252, P(8T), Upper Callovian, Pedrógão, Portugal, L =0.476, H=0.324; 5, o C, dorsal view, SMF Xe 23253, P(8T), Upper Callovian, Pedrógão, Portugal, L = 0.450, H=0.274. (6-9) Theriosynoecum helmdachi Sohn, 1982: 6, ㅇ C, left view, external, SMF Xe 23254, P(8B), Upper Callovian, Pedrógão, Portugal, L =1.1, H=0.650; 7, ९ C (as 6), external, ornament detail, posterior tubercle; 8, RV, external, juv., SMF Xe 23255, P(8T), Upper Callovian, Pedrógão, Portugal, $\mathrm{L}=0.650, \mathrm{H}=0.4 ; \mathbf{9}$, C (as 6), external, ornament detail, ventral lateral ridge. $(\mathbf{1 0}, 11)$ Theriosynoecum sp. 1: 10, C, dorsal view, juv., SMF Xe 23256, P(6), Upper Callovian, Pedrógão, Portugal, $\mathrm{L}=0.675, \mathrm{H}=0.4 ; \mathbf{1 1}, \mathrm{C}$, left view, juv. SMF Xe 23257, P(6), Upper Callovian, Pedrógão, Portugal, $\mathrm{L}=0.624, \mathrm{H}=0.375$. (12, 13) Septacandona azeredae Cabral \& Colin, 2000: 12, C, right view, external, SMF Xe 23258, P(6), Upper Callovian, Pedrógão, Portugal, $\mathrm{L}=0.625, \mathrm{H}=0.225 ; \mathbf{1 3}, \mathrm{C}$ (as 12), external, ornament detail. (14-17) Mantelliana spp.: 14, LV, external, SMF Xe 23259, P(8T), Upper Callovian, Pedrógão, Portugal, L = 0.624, H=0.350; 15, ᄋ RV, external, SMF Xe 23260, $\mathrm{P}(10)$, Upper Callovian, Pedrógão, Portugal, $\mathrm{L}=0.624, \mathrm{H}=0.350 ; 16$, đ C, left view, external, SMF Xe 23261, $\mathrm{P}(8 \mathrm{~T})$, Upper Callovian, Pedrógão, Portugal, $\mathrm{L}=0.575, \mathrm{H}=0.324 ; 17$, o C, left view, external, SMF Xe 23262, $\mathrm{P}(8 \mathrm{~T})$, Upper Callovian, Pedrógão, Portugal, $\mathrm{L}=0.575, \mathrm{H}=0.350$

(18) Alicenula cf. A. incurva (Bate, 1967): C, right view, external, SMF Xe 23263, P(10), Upper Callovian, Pedrógão, Portugal, $\mathrm{L}=1.024, \mathrm{H}=0.425$. (19) Alicenula sp. 1: C, right view, external, SMF Xe 23264, P(10), Upper Callovian, Pedrógão, Portugal, $\mathrm{L}=0.550, \mathrm{H}=0.250$. (20) Alicenula sp. 2: LV, external, SMF Xe 23265, P(10), Upper Callovian, Pedrógão, Portugal, L =1.0, H=0.525. Scale bars $100 \mu \mathrm{m}$ except where otherwise noted. 
Wilkinson \& Whatley (2009) (g) and N. composita (Wienholz, 1967) (h); arrows indicate points for comparison. Even allowing for some variation between $\$$ and $\delta^{\star}$, it is clear that the LVs of multiforma sp. nov. are closest to $N$. caesa caesa of Wilkinson \& Whatley, especially the dorsal rib (1) but differ in ornament posteriorly; neither is closely comparable with Triebel's holotype (e). Neurocythere caesa subsp. A of Wilkinson \& Whatley (f) is the closest to the holotype (e). Another apparently close form is N. composita (Wienholz, 1967) from the Callovian of NE Germany (h). Figure 10 compares the holotype of $N$. composita of Wienholz (Fig. 10h) with the holotype of N. caesa caesa (Triebel, 1951) (Fig. 10e) and multiforma sp. nov. (Fig. 10a) - the fundamental rib patterns of the three taxa clearly differ, especially in relation to the dorsalmost rib.

\section{Family Limnocytheridae Klie, 1938}

Genus Sinuocythere Colin, Cabral, Dépêche \& Mette, 2000

Type species. Metacypris sinuosa Mette, 1995.

Sinuocythere pedrogaensis Cabral \& Colin, 2000 in Colin et al. (2000)

(Fig. 11:4-5)

2000 Sinuocythere pedrogaensis Cabral \& Colin, in Colin et al: 126, pl. 2, figs 11-14, pl. 3, figs 1-7.

Material. 18 valves and carapaces: samples $\mathrm{P}(8 \mathrm{~B}), \mathrm{P}(8 \mathrm{~T}), \mathrm{P}(10)$.

Description. See Colin et al. (2000, 126).

Dimensions. $\mathrm{L}=0.375-0.500, \mathrm{H}=0.250-0.325$.

Occurrence. Described from the Oxfordian of Pedrógão by Cabral \& Colin (in Colin et al. 2000), also reported from the Upper Callovian and Oxfordian of Vermoil (Cabral et al. 2003) and in the Oxfordian of Serra do Bouro (Azerêdo et al. 2010); athleta Zone, Upper Callovian, Pedrógão (this work).

Remarks. At present known only from Portugal.

Genus Theriosynoecum Branson, 1936

Type species. Morrisonia wyomingensis Branson, 1935.

Theriosynoecum helmdachi Sohn, 1982

(Fig. 11:6-9)

non 1935 Morrisonia wyomingensis Branson: 521, pl. 57, figs 17-21. 1971 Theriosynoecum wyomingensis (Branson); Helmdach: 62, text-figs 5-7.

1974 Theriosynoecum wyomingensis (Branson); Helmdach: 14, text-fig. 4.

1982 Theriosynoecum helmdachi Sohn: 312-313.

2002 a Theriosynoecum wyomingensis (Branson); Azerêdo et al.: 161, pl. 2, fig. 1.

Material. 17 specimens - adults and juveniles, valves and carapaces: samples $\mathrm{P}(8 \mathrm{~B}), \mathrm{P}(8 \mathrm{~T}), \mathrm{P}(10)$.

Dimensions. $\mathrm{L}=1.125-1.175, \mathrm{H}=0.575-0.625$.

Occurrence. Originally reported from the Kimmeridgian of the Guimarota mine (1 km south of Leiria, Fig. 1) and CallovianOxfordian of Pedrógão, Portugal (e.g. Helmdach 1971, 1974), T. helmdachi is known from other Portuguese Jurassic outcrops, being particularly abundant in the Oxfordian (Cabral et al. 1998, 1999, 2001, 2003; Azerêdo et al. 2002a); athleta Zone, Upper Callovian, Pedrógão (this work).

Remarks. In carapace morphology our material resembles $T$. wyomingensis (Branson, 1935), a species described from the Upper Jurassic-Lower Cretaceous of the North American west and refigured by Sylvester-Bradley (1973) using material provided by Branson. For many years authors, particularly Helmdach (e.g. Helmdach 1971, 1974), Schudack (e.g. 2000) and Azerêdo et al. (2002a), ascribed Portuguese material to the North American taxon. Sohn (1982) described a new species, T. helmdachi, based on some morphological differences between the Portuguese and the North American specimens. The Portuguese species differs from the American one in 'having a more subdued ventrolateral ridge and a curved liplike offset of the overlapping valve on the ventral margin in front of midlength' (Sohn 1982, 313) and also in its weaker and shorter median sulcus; moreover, in all the studied Portuguese material, particularly in the specimens from the Oxfordian (M.C. Cabral ongoing work; Azerêdo et al. 2002a) the second, more posterior vertical sulcus is less pronounced than in the American ones. As these morphological differences are evident, allowing for the morphological variability considered normal for the genus, we prefer to follow the Sohn classification. Material not well preserved.

\section{Theriosynoecum $\mathrm{sp} .1$}

(Fig. 11:10-11)

Material. 5 specimens - juveniles, carapaces: sample $\mathrm{P}(6)$. athleta Zone, Upper Callovian, Pedrógão (this work).

Description. Quadrate, weak dorso-median sinus, reticulate; internal features unknown.

Dimensions. $\mathrm{L}=0.625-0.700, \mathrm{H}=0.400-0.450$.

Remarks. This is probably juvenile material of T. fluxans spiculata (Helmdach, 1972) already recorded from Pedrógão at the same horizon (Azerêdo et al. 2002a, 161).

Suborder Cypridocopina Baird, 1845 Superfamily Cypridoidea Baird, 1845 Family Candonidae Kaufmann, 1900

Genus Septacandona Cabral \& Colin, 2002

Type species. Septacandona ramalhoi Cabral \& Colin, 2002.

Septacandona azeredae Cabral \& Colin, 2002

(Fig. 11:12-13)

2002 Septacandona azeredae Cabral \& Colin: 68, figs 6A-K. 2002 a Septacandona azeredae Cabral \& Colin; Azerêdo et al.: 161, pl. 3 , fig. 7 .

2010 Septacandona azeredae Cabral \& Colin; Azerêdo et al.: 9, pl. 2, figs $12-13$.

Material. 1C, same bed as sample $\mathrm{P}(6)$ of this work, sampled laterally (1998).

Description. See Cabral \& Colin $(2002,68,70)$.

Dimensions. $\mathrm{L}=0.600, \mathrm{H}=0.260$ (deformed).

Occurrence. Described from the Oxfordian of Vale de Ventos, Lusitanian Basin, Portugal, was later found in Valverde (Cabral 
et al. 2001) and in Serra do Bouro (Azerêdo et al. 2010), the three outcrops exhibiting similar facies types. The occurrence in the athleta Zone, Upper Callovian, Pedrógão (this work) is the oldest record of the species and the first one in the west of the basin, with more margino-marine facies.

Remarks. The only specimen is poorly preserved and deformed, but it is certainly $S$. azeredae, regarding its typical trapezoidal lateral outline, ornamentation represented by horizontal ribs in the central part of the valves and presence of a very weak median vertical sulcus.

\section{Family Cyprididae Baird, 1845}

Genus Mantelliana Anderson, 1966

Type species. Candona mantelli Jones, 1888.

\section{Mantelliana spp. \\ (Fig. 11:14-17)}

Material. 39 specimens - adults, carapaces and valves: samples $\mathrm{P}$ (8B), $\mathrm{P}(8 \mathrm{~T})$.

Dimensions. $\mathrm{L}=0.550-0.675, \mathrm{H}=0.275-0.375$.

Remarks. The material appears to represent two species (one species shown in Fig. 11:14-15 and a second species in Fig. 11:16-17) although the latter is crushed - athleta Zone, Upper Callovian, Pedrógão (this work). Gen. ind. n. sp. O-16 of Azerêdo et al. $(2002 a, 2010)$ is a Mantelliana.

Suborder Darwinulocopina Brady \& Norman, 1889 Superfamily Darwinuloidea Brady \& Norman, 1889 Family Darwinulidae Brady \& Norman, 1889

Genus Alicenula Rossetti \& Martens, 1998

Type species. Darwinula serricaudata Klie, 1935.

Alicenula cf. A. incurva (Bate, 1967)

(Fig. 11:18)

cf. 1967 Darwinula incurva Bate: 28 -29, pl. 1, figs 7-12. cf. 1994 Darwinula incurva Bate, 1967; Wakefield: 64, pl. 11, figs $1-4,7$.

2002a Darwinula n. sp. 2 Azerêdo et al.: 161; pl. 3, fig 2.

cf. 2009 Alicenula incurva (Bate, 1967); Wakefield: 239, pl. 1, fig. 17.

Material. 8 specimens - valves and carapaces: samples $\mathrm{P}(8 \mathrm{~B}), \mathrm{P}$ (8T), $\mathrm{P}(10)$.

Description. Elongate outline; LV overlaps RV around all margins; greatest length at mid-height, greatest height and greatest width at mid-length. Dorsal margin straight to slightly convex, anterior and posterior margins rounded, ventral margin straight becoming slightly concave anteriorly. Valve surface smooth. Internal features unknown.

Dimensions. $\mathrm{L}=1.025-1.125, \mathrm{H}=0.425-0.500$.

Occurrence. Oxfordian of Pedrógão (Cabral et al. 1998; Azerêdo et al. 2002a); athleta Zone, Upper Callovian, Pedrógão (this work).

Remarks. Material poorly preserved but with some similarity to $A$. incurva from the Bathonian of Britain (figured material of
Wakefield (1994) compared). Alicenula incurva is larger than our material with a stronger ventral marginal concavity.

$$
\begin{gathered}
\text { Alicenula } \text { sp. } 1 \\
\text { (Fig. 11:19) }
\end{gathered}
$$

?2010 Darwinula n. sp. 2 Azerêdo et al.: 8, pl. 2, fig 15.

Material. About 11 specimens - carapaces and valves: samples $\mathrm{P}$ (8B), $\mathrm{P}(8 \mathrm{~T})$.

Description. Elongate outline, valves of similar size; greatest length just below mid-height, greatest height towards posterior, greatest width at mid-length. Dorsal margin weakly convex, anterior margin rounded incurvate, posterior margin rounded, ventral margin weakly convex. Internal features unknown.

Dimensions. $\mathrm{L}=0.375-0.550, \mathrm{H}=0.250-0.300$.

Occurrence. ?Oxfordian of Serra do Bouro (Azerêdo et al. 2010); athleta Zone, Upper Callovian, Pedrógão (this work).

Remarks. Alicenula incurva, $A$. sp. 1 and $A$. sp. 2 differ from each other in L:H ratio and position of greatest height posteriorly. Poorly preserved.

\section{Alicenula sp. 2 \\ (Fig. 11:20)}

2002 a Darwinula n. sp. 1 Azerêdo et al.: 161, pl. 3, fig 1 . 2010 Darwinula n. sp. 1 Azerêdo et al:: 8, pl. 2, fig 14.

Material. 3 RV: samples $\mathrm{P}(8 \mathrm{~T}), \mathrm{P}(10)$.

Description. Elongate subovate outline; greatest length ventral of mid-height, greatest height posterior, greatest width at two-thirds of length. Dorsal margin convex, anterior margin rounded incurvate, posterior margin rounded, ventral margin slightly concave. Valve surface smooth. Internal features unknown.

Dimensions. $\mathrm{L}=0.900-1.000, \mathrm{H}=0.500-0.525$.

Occurrence. Oxfordian of Pedrógão (Cabral et al. 1998; Azerêdo et al. 2002a), of Vale de Ventos (Cabral et al. 1999; Azerêdo et al. 2002a), of Vermoil (Cabral et al. 2003) and of Serra do Bouro (Azerêdo et al. 2010); athleta Zone, Upper Callovian, Pedrógão (this work).

Remarks. Poorly preserved.

\section{Indeterminate taxa}

Genus and species indeterminate 1

(Fig. 11:1)

Material. 1 carapace: sample $\mathrm{P}(-8)$.

Dimensions. $\mathrm{L}=0.624, \mathrm{H}=0.250$.

Remarks. With its straight ventral margin and continuously curved convex anterior, dorsal and posterior margins this form may be related to Acratia Delo. Valve surface appears smooth but poorly preserved. Internal features unknown.

Genus and species indeterminate 2 (Fig. 7:20-22) 
Material. 17 carapaces: samples $\mathrm{P}(-4 \mathrm{~T}), \mathrm{P}(-2), \mathrm{P}(0), \mathrm{P}(6)$.

Description. Subovate and elongate outline, small size; LV $>$ RV except along dorsal margin where $\mathrm{RV}>\mathrm{LV}$; greatest length just ventral of mid-height, greatest height at anterior cardinal angle, greatest width at mid-length. Dorsal and ventral margins straight and almost parallel. Anterior margin rounded and infracurvate, posterior subtriangular. Some variation in the posterior margin observed, from subtriangular to subrounded. Valve surface smooth. Sexual dimorphism not observed. Internal features unknown.

Dimensions. $\mathrm{L}=0.400-0.425, \mathrm{H}=0.200-0.225$.

Remarks. Rounded podocopid species of uncertain affinity.

Genus and species indeterminate 3

(Fig. 11:2-3)

Material. 3 carapaces: samples $\mathrm{P}(0), \mathrm{P}(2 \mathrm{M})$.

Dimensions. $\mathrm{L}=0.375-0.500, \mathrm{H}=0.200-0.225$.

Remarks. Rounded podocopid species, internal features unknown, affinity uncertain.

\section{Discussion}

The Pedrógão section yielded marine ostracods and calcareous nannoplankton from samples $\mathrm{P}(-8)$ to $\mathrm{P}(6)$ and few, poorly preserved and reworked non-marine ostracods from overlying samples $\mathrm{P}(8 \mathrm{~B})$ to $\mathrm{P}(10)$.

\section{Taxonomic problems}

When undertaking this study we anticipated finding ostracod taxa from the classic literature on the marine Callovian of NW Europe. At the genus level this was true, as represented by cytheroids Micropneumatocythere, Neurocythere, Palaeocytheridea, Patellacythere, Praebythoceratina, Praeschuleridea and Tanycythere accompanied by Cytherella, Cytherelloidea and Polycope; however, noteworthy absences included Eucytherura Müller and related taxa, Fastigatocythere Wienholz, Fuhrbergiella Brand \& Malz, Galliaecytheridea Oertli, Glyptocythere Brand \& Malz, Lophocythere Sylvester-Bradley, Pleurocythere Triebel, Progonocythere Sylvester-Bradley, and other small cytheroids, no bairdioids and only a single marine cypridoid. Indeed, the marine assemblages are of notably low diversity compared with coeval material from NW Europe, which may reflect a nearshore environment with lowered and/or fluctuating salinity. At the species level we were able to identify only a single previously described taxon (Gen. nov.? gublerae), all other species were either new, indigenous to Portugal or could be compared (cf.) only with described taxa.

The taxonomic difficulties are well illustrated by Neurocythere multiforma sp. nov. which presented two problems: (1) similarity to but not precise identity with known species of the genus (discussed in Systematic Palaeontology), and (2) the presence of a range of morphological variation that we interpret as three forms of a single species. As discussed above, N. multiforma occurs as Morphotypes I-III with males and females in 11 successive samples and may represent contemporaneous, interbreeding populations. We are aware of current thought about taxonomic harmonization for 'near time' Quaternary-Recent species as a practical way to increase the utility of ostracod species for environmental monitoring and reconstruction (a heueristic approach: Horne et al. 2011, 2015; Danielopol et al. 2015). With 'deep time' taxa the palaeontologist lacks information on (1) genetic characteristics, and usually (2) appendages and soft part anatomy, and (3) reproductive strategies, and must rely on the features of the calcified valve to define a species, an approach where differences are more apparent than similarities. Based solely on carapace characteristics, N. multiforma sp. nov. represents a single biological species. How did the three morphotypes live together? One possible model of niche-partitioning is provided by Ikeya \& Shimura (1995) who reported three species of Spinileberis Hanai from a tidal zone environment in Japan. Based on appendage and carapace characteristics the three species are distinct and were not observed to interbreed. The cooccurrence of three biological species of the same genus was explained by the possession of different reproductive and growth strategies, and also by the possibility that some very local bottomwater habitats were close to freshwater salinity. Other examples of sympatric speciation, perhaps less clear because from non-marine environments, concern Miocene Cyprideis Jones from Amazonia (Gross et al. 2014) where up to 12 species are considered to occur sympatrically, and Cyprideis from Austria (Gitter et al. 2015) where four apparently co-existing Cyprideis species are referred to different microhabitats based on salinity preferences. Whatever the biological or ecological rationale behind these cases, on present evidence we prefer to recognize three morphotypes of multiforma which may, or may not, represent three co-existing sympatric species reflecting some kind of original niche-partitioning and not a simple taphonomic signal. However, the morphological distinction between N. multiforma sp. nov. Morphotypes III and II is much less clear than between Morphotype I and the others, and III and II could be interpreted as reflecting a range of variation while $I$ is polymorphic with them (see Neil (2000) for an overview).

\section{Palaeobiogeography, faunal links and faunal dynamics}

In recent years knowledge of Middle and Upper Jurassic ostracods from the eastern Tethys has steadily increased and there is now a reasonably sized database for reconstruction of palaeobiogeographical and stratigraphical distribution patterns, although time correlations are often imprecise through lack of ammonite-based zonation schemes. Andreu et al. (2012) list material from Kachchh, India and analyse ostracod distribution patterns at genus and species levels from sites around the coast of East and West Gondwana and compare them with more boreal areas including Europe (they also provide a good reference list). The cytheroids evolved rapidly during the Jurassic and are thus key comparators. Our Portuguese material has little in common with the Indo-East African Province fauna of Andreu et al. (2012), i.e. of Australia, East Africa, India and Madagascar, with the absence of key genera such as Majungaella Grékoff, Mandawacythere Bate and Trichordis Grékoff. For the Callovian, Andreu et al. (2012, figs 19-20) list three genera in common between the Indo-East African Province and Europe, namely Fastigatocythere Wienholz, Procytheridea Peterson and Progonocythere SylvesterBradley, none of which is present in our material. Fastigatocythere and Progonocythere were originally described from Europe. Fastigatocythere is particularly diverse in eastern Tethys, e.g. India. A number of Tethyan species have been assigned to Progonocythere but probably require re-examination in light of the revision of the genus by Whatley \& Ballent (1996). A number of Indian and other species have been placed in Procytheridea but may also require revision if Lord (1972) and Sherrington \& Lord (1975a, b) are correct that genus is restricted to North America.

The Pedrógão assemblages have cytheroid elements in common with Saudi Arabia (Virgulacytheridea), Israel (Gen. nov? gublerae) and Tunisia (Sinuocythere) but it is striking how different and less diverse the Portuguese material is when compared with Callovian material from, for example, Tunisia (Mette 1995, 1997). Thus, links between Portugal and NW Europe at species level are weak (only cf. species), at genus level slightly better but from low diversity assemblages, and to the western Tethys also weak. 
We encountered a number of species which exhibited subtle morphological differences with described material with obvious consequences for taxonomy. The difficulty was compounded when type material was compared with our current and published material. Many minor, and not so minor, morphological differences became clear amongst published figured material which indicate that there is considerable variation amongst established species yet to be explored.

\section{Conclusions}

Ostracod assemblages from the upper Callovian of western Portugal yielded (1) a marine association of 17 species: 5 species described as new (Praebythoceratina parascrobiculata, Praeschuleridea lisensis, Neurocythere multiforma, Virgulacytheridea posteroacuminata, Palaeocytheridea (M.)? dorsocostata), 1 previously described species (Gen. nov.? gublerae), 6 species compared with described taxa (Polycope cf. P. sububiquita, Cytherella cf. C. fullonica, C. cf. C. index, Cytherelloidea cf. Ca. chonvillensis, Patellacythere cf. P. ungulina, Praebythoceratina cf. Pr. stimulea), and 5 species in open nomenclature; and (2) a non-marine association of 8 species: 3 species previously described (Septacandona azeredae, Theriosynoecum helmdachi, Sinuocythere pedrogaensis), 1 species compared with a described taxon (Alicenula cf. A. incurva), and 4 species in open momenclature. The non-marine component in samples $\mathrm{P}(8 \mathrm{~B})$ to $\mathrm{P}(10)$ is generally poorly preserved and reworked and contains three species indigenous to Portugal. The number of new marine taxa was surprising. These conclusions are based on subtle morphological differences with described marine taxa, which were also unexpected. In the last two decades ostracod research has focused on Quaternary-Recent material and the reconstruction of environmental change in near time. Our results demonstrate that there are research opportunities in Mesozoic ostracod biodiversity, faunal interchange, biogeographical patterns and the controlling biotic and abiotic influences. This is especially true for ostracods of the superfamily Cytheroidea, which has been a particular focus of dynamic speciation since the early Jurassic (200 Ma), and whose rates of evolution and speciation dynamics require examination.

\section{Acknowledgements and Funding}

We are indebted to many colleagues for help and discussion: D.L. Danielopol (Graz), F. Dépêche (Paris), A. Honigstein (Geological Survey of Israel, Jerusalem), D.J. Horne (London), J. Sauvagnat (Geneva), E. Tesakova (Moscow), and for the loan of material to: A. Ehling (Bundesanstalt für Geowissenschafter und Rohstoffe, Berlin) and S. Stukins (The Natural History Museum, London). We thank C. Franz and M. Ricker (Senckenberg Forschungsinstitut) and Vera Lopes and Telmo Nunes (Universidade de Lisboa) for preparation of diagrams and help with scanning and light microscopy. We thank the constructive comments of two anonymous reviewers.

VP gratefully acknowledges the support of the Senckenberg Forschungsinstitut during a six-month ERASMUS traineeship in Frankfurt.

This is a contribution to Project PDCTE/CTA/44907/2002 funded by Fundação para a Ciência e Tecnologia, Portugal.

Scientific editing by Elisabeth Brouwers

\section{References}

Alexander, C.I. 1929. Ostracoda of the Cretaceous of North Texas. University of Texas Bulletin, 2907, 1-137.

Alméras, Y., Ruget, C., Carapito, M.C., Cariou, E. \& Mouterde, R. 1991. Biostratigraphie du Callovien de Pedrógão: le Portugal voie d'échanges fauniques au Callovien. Memórias e Notícias, Publicações do Museu e Laboratório Mineralógico e Geológico da Universidade Coimbra, 112, 239-246.

Anderson, F.W. 1966. New genera of Purbeck and Wealden Ostracoda. Bulletin of the British Museum (Natural History), Geology, 11, 435-446.

Andreu, B., Colin, J-P. \& Singh, J. 2012. Middle and Upper Jurassic Ostracods from Western Kachchh, Gujarat, India: Biostratigraphy and paleobiogeography. Gondwana Research, 22, 1110-1124.
Azerêdo, A.C., Cabral, M.C., Ramalho, M.M. \& Pereira, R. 2002a. Overview of microfossil assemblages and palaeoecological signatures in the Middle-Upper Jurassic transitional successions from the Lusitanian Basin, Portugal. Comunicações do Instituto Geológico e Mineiro, 89, 135-158.

Azerêdo, A.C., Wright, V.P. \& Ramalho, M.M. 2002b. The Middle-Late Jurassic forced regression and disconformity in central Portugal: eustatic, tectonic and climatic effects on a carbonate ramp system. Sedimentology, 49, 1339-1370.

Azerêdo, A.C., Duarte, L.V., Henriques, M.H. \& Manuppella, G. 2003. Da dinâmica continental no Triásico aos Mares do Jurássico Inferior e Médio. Cadernos de Geologia de Portugal, Instituto Geológico e Mineiro, Lisboa.

Azerêdo, A.C., Cabral, M.C., Martins, M.J., Loureiro, I.M. \& Inês, N. 2010. Estudo estratigráfico dum novo afloramento da Formação de Cabaços (Oxfordiano) na região da Serra do Bouro (Caldas da Rainha). Comunicações Geológicas, 97, 5-22.

Azerêdo, A.C., Duarte, L.V. \& Silva, R.L. 2014. Configuração sequencial em Ciclos ( $2^{\mathrm{a}}$ ordem) de Fácies Transgressivas-Regressivas do Jurássico Inferior e Médio da Bacia Lusitânica (Portugal). Comunicações Geológicas, 101 (Especial I), 383-386.

Baird, W. 1845. Arrangement of the British Entomostraca, with a list of species, particularly noticing those which have as yet been discovered within the bounds of the Club. Transactions of the Berwickshire Naturalists' Club, 2, $145-158$.

Baird, W. 1850. The Natural History of the British Entomostraca. Ray Society, London.

Barrón, E. \& Azerêdo, A.C. 2003. Palynological study of the Jurassic (CallovianOxfordian) succession from Pedrógão (Lusitanian Basin, Portugal). Palaeoecological and palaeobiogeographical aspects. Neues Jahrbuch für Geologie und Paläontologie, Abhandlungen, 227, 259-286.

Barrón, E., Azerêdo, A.C., Cabral, M.C., Ramalho, M.M. \& Pereira, R. 1999. Palinomorfos del Jurásico de Pedrógão (Portugal). Descripción y comparación con otros elementos micropaleontológicos y sedimentológicos. Temas Geológico-Mineros, Instituto Tecnológico Geominero de España, 26, 186-191.

Bate, R.H. 1963. Middle Jurassic Ostracoda from north Lincolnshire. Bulletin of the British Museum (Natural History), Geology, 8, 173-219.

Bate, R.H. 1964. Middle Jurassic Ostracoda from the Millepore Series, Yorkshire Bulletin of the British Museum (Natural History), Geology, 10, 1-61.

Bate, R.H. 1967. The Bathonian Upper Estuarine Series of eastern England Part I: Ostracoda. Bulletin of the British Museum (Natural History), Geology, 14 21-66.

Bate, R.H. 1969. Some Bathonian Ostracoda of England with a revision of the Jones, 1884, and Jones and Sherborn, 1888, collections. Bulletin of the British Museum (Natural History), Geology, 17, 377-437.

Bate, R.H. 1975. Ostracods from Callovian to Tithonian sediments of Tanzania, East Africa. Bulletin of the British Museum (Natural History), Geology, 26, 161-223.

Bate, R.H. 2009. Middle Jurassic (Aalenian-Bathonian). In: Whittaker, J.E. \& Hart, M.B. (eds) Ostracods in British Stratigraphy. The Micropalaeontological Society, Special Publications, 199-223.

Bate, R.H. \& Sheppard, L.M. 1979. The ostracod genus Micropneumatocythere in the Middle Jurassic of England. Revista Española de Micropaleontología, 11, 79-94.

Bergen, J.A., Boesiger, T.M. \& Pospichal, J.J. 2013. Low-latitude Oxfordian to Early Berriasian nannofossil biostratigraphy and its application to the subsurface of eastern Texas. In: Hammes, U. \& Gale, J. (eds) Geology of the Haynesville Gas Shale in East Texas and West Louisiana, U.S.A. American Association of Petroleum Geologists, Memoir, 105, 69-102.

Bizon, J.J. 1958. Foraminifères et Ostracodes de l'Oxfordien de Villers-sur-Mer (Calvados). Revue de l'Insitute Français du Pétrole, 13, 3-45.

Bonnema, J.H. 1941. Ostracoden aus der Kreide des Untergrundes der nordöstlichen Niederlande. Natuurhistorisch Maandblad, 30, 8-10.

Bown, P. (ed.) 1998. Calcareous Nannofossil Biostratigraphy. Chapman \& Hall/ Kluwer Academic, London.

Bown, P. \& Cooper, M.K.E. 1998. Jurassic. In: Bown, P. (ed.) Calcareous Nannofossil Biostratigraphy. Chapman \& Hall/Kluwer Academic, London, 34-85.

Bown, P. \& Young, J.R. 1998. Techniques. In: Bown, P. (ed.) Calcareous Nannofossil Biostratigraphy. Chapman \& Hall/Kluwer Academic, London, 16-28.

Bown, P.R., Cooper, M.K.E. \& Lord, A.R. 1988. A calcareous nannofossil biozonation scheme for the early to mid Mesozoic. Newsletters in Stratigraphy, 20, 91-114.

Brady, G.S. \& Norman, A.M. 1889. A monograph of the marine and freshwater Ostracoda of the North Atlantic and of northwestern Europe. I: Podocopa. Scientific Transactions of the Royal Dublin Society, series 2, 4, 63-270.

Bralower, T.J., Monechi, S. \& Thierstein, H.R. 1989. Calcareous nannofossil zonation of the Jurassic-Cretaceous boundary interval and correlation with the geomagnetic polarity timescale. Marine Micropaleontology, 14, 153-235.

Brand, E. 1990. Biostratigraphische Untergliederung des Ober-Bathonium im Raum Hildesheim, Nordwest-deutschland mittels Ostracoden und Korrelation ihrer Vertikalreichweiten mit Ammoniten-Zonen. Geologisches Jahrbuch, A121, 119-273.

Branson, C.C. 1935. Fresh-water invertebrates from the Morrison (Jurassic?) of Wyoming. Journal of Paleontology, 9, 514-522. 
Branson, C.C. 1936. New name for a Morrison ostracode genus. Journal of Paleontology, 10, 323.

Cabral, M.C. \& Colin, J-P. 2002. Taxonomie et paléoécologie de nouveaux ostracodes limniques Candonidae dans l'Oxfordien (Jurassique supérieur) du Portugal. Geodiversitas, 24, 61-76.

Cabral, M.C., Azerêdo, A.C. \& Ramalho, M.M. 1998. Estudo preliminary dos Ostracodos de Pedrógão (passagem Dogger-Malm). Comunicações do Instituto Geológico e Mineiro, 84, A74-A77.

Cabral, M.C., Azerêdo, A.C. \& Ramalho, M.M. 1999. Les Ostracodes de Vale de Ventos ( passage Dogger-Malm) - résultats préliminaires. Abstracts European Palaeontological Association Workshop, Lisboa, 21-25.

Cabral, M.C., Azerêdo, A.C. \& Ramalho, M.M. 2001. Ostracodos do Jurássico Superior de Valverde (Bacia Lusitânica, Portugal): estudo preliminar. Publicaciones del Seminario de Paleontología de Zaragoza, 5.1, 68-73.

Cabral, M.C., Azerêdo, A.C. \& Ramalho, M.M. 2003. Microfauna (ostracodos foraminiferos) do Caloviano-Oxfordiano da sondagem Vermoil-1, Leiria: estudo preliminar e comparação com a da série de Pedrógão. Ciências da Terra, Universidade Nova Lisboa, Lisboa, $\mathrm{n}^{\circ}$ esp. V (CD ROM), A11-A14.

Cabral, M.C., Lord, A., Boomer, I., Loureiro, I. \& Malz, H. 2014. Tanycythere new genus and its significance for Jurassic ostracod diversity. Journal of Paleontology, 88, 519-530.

Carapito, M.C. 1998. Biostratigrafia do Caloviano-Oxfordiano do Cabo Mondego. In: Tomás Oliveira, J. \& Dias, R.P. (eds) Livro Guia das Excursões, $V$ Congresso Nacional de Geologia. Instituto Geológico e Mineiro, Lisboa, 65-69.

Carapito Krausshar, C. 2008. Estratigrafia e biostratigrafia do BatonianoOxfordiano do Cabo Mondego (Perfil da Praia). In: Callapez, P.M., Rocha, R.B., Marques, J.F., Cunha, L.S. \& Dinis, P.M. (eds) A Terra, Conflitos e Ordem, Homenagem ao Professor Ferreira Soares. Museu e Laboratório Mineralógico e Geológico da Universidade de Coimbra, Coimbra, 187-195.

Castellato, C.E. 2010. Calcareous nannofossil biostratigraphy of Upper Callovian-Lower Berriasian successions from the southern Alps, North Italy. Revista Italiana di Paleontologia e Stratigrafia, 116, 357-404.

Colin, J-P., Cabral, M.C., Dépêche, F. \& Mette, W. 2000. Sinuocythere n. gen. (Ostracoda, Limnocytheridae, Timiriaseviinae), a new genus of limnic ostracode from the southern Tethyan Middle and Upper Jurassic. Micropaleontology, 46, 123-134.

Danielopol, D.L., Namiotko, T., von Grafenstein, U., Fuhrmann, R., Decrouy, L., Gross, M. \& Picot, L. 2015. The implementation of taxonomic harmonisation for Candoninae (Ostracoda, Cypridoidea). A heuristic solution fo Fabaeformiscandona tricicatricosa (Diebel \& Pietrzeniuk). 8th European Ostracodologists' Meeting, University of Tartu, Estonia, Abstracts, 22.

Dépêche, F. 1969. Les Ostracodes du Callovien inférieur et moyen du sondage Chonville 1 (Meurthe et Moselle, France). Bulletin du Centre de Recherches Pau, 3, 259-285.

Dépêche, F. 1985. Lias supérieur, Dogger, Malm. In: Oertli, H.J. (ed.) Atlas des Ostracodes de France (Paléozoïque-Actuel). Bulletin du Centre de Recherches Exploration-Production Elf-Aquitaine, Mémoir, 9, 119-145.

Dépêche, F., Le Nindre, Y-M., Manivit, H. \& Vaslet, D. 1987. Les ostracodes du Jurassique d'Arabie Saoudite centrale: systematique, repartition stratigraphique et paleogeographique. Geobios, Mémoire spécial, 9, 221-275.

Donze, P. 1962. Contribution a l'étude paléontologique de l'Oxfordien Supériezr de Trept (Isère). III. Ostracodes. Travaux des Laboratoires de Géologie de la Faculte des Sciences de Lyon, Nouvelle Serie, 8, 125-142.

Fischer, W. 1962. Ostracoden der gattungen Monoceratina Roth 1928, Cytheropteron G.O.Sars 1865 und andere im Lias Zeta Schwabens. Neues Jahrbuch für Geologie und Paläontologie, Abhandlungen, 114, 333-345.

Franz, M., Tesakova, E. \& Beher, E. 2009. Documentation and revision of the index ostracods from the Lower and Middle Jurassic in SW Germany according to Buck (1954). Palaeodiversity, 2, 119-167.

Gitter, F., Gross, M. \& Piller, W.E. 2015. Sub-decadal resolution in sediments of Late Miocene Lake Pannon reveals speciation of Cyprideis (Crustacea, Ostracoda). PloS One, 10, e0109360.

Glashoff, H. 1964. Ostrakoden-Faunen und Paläogeographie im Oxford NWEuropas. Paläontologische Zeitschrift, 38, 28-65.

Gradstein, F.M., Ogg, J.G., Schmitz, M.D. \& Ogg, G.M. 2012. The Geologic Time Scale 2012. Elsevier, Amsterdam.

Grambast-Fessard, N. \& Ramalho, M.M. 1985. Charophytes du Jurassique supérieur du Portugal. Revue de Micropaléontologie, 28, 58-66.

Grékoff, N. 1963. Contribution à l'étude des ostracodes du Mésozoïque moyen (Bathonian-Valanginian) du Bassin de Majunga. Revue de l'Insitute Français du Pétrole, 18, 1709-1762.

Gross, M., Ramos, M.I.F. \& Piller, W.E. 2014. On the Miocene Cyprideis species flock (Ostracoda; Crustacea) of Western Amazonia (Solimões Formation) Refining taxonomy on species level. Zootaxa, 3899, 1-69.

Gründel, J. \& Kozur, H. 1971. Zur taxonomie der Bythocytheridae und Tricornidae (Podocopida, Ostracoda). Monatsberichte der Deutschen Akademie der Wissenschaften zu Berlin, 13, 907-937.

Helmdach, F.F. 1971. Stratigraphy and ostracod-fauna from the coalmine Guimarota (Upper Jurassic). Serviços Geológicos de Portugal, Memória, 17 (NS), 41-88.

Helmdach, F.F. 1972. Ontogenie und Ornamentierung einiger oberjurassischer Arten von Bisulcocypris (Ostracoda). Neues Jahrbuch für Geologie und Paläontologie, Abhandlungen, 141, 286-300.
Helmdach, F.F. 1974. A contribution to the stratigraphical subdivision of nonmarine sediments of the Portuguese Upper Jurassic. Comunicações dos Serviços Geológicos de Portugal, 57, 5-21.

Herngreen, G.F.W., De Boer, K.F., Romein, B.J., Lissenberg, T. \& Wijker, N.C 1984. Middle Callovian Beds in the Achterhoek, Eastern Netherlands. Mededelingen Rijks Geologische Dienst, 37, 1-29.

Herrig, E. 1966. Ostracoden aus der Weißen Schreibkreide (Unter-Maastricht) der Insel Rügen. Paläontologische Abhandlungen, A2, 693-1024.

Horne, D.J., Cohen, A. \& Martens, K. 2002. Taxonomy, morphology and biology of Quaternary and living Ostracoda. In: Holmes, J.A \& Chivas, A.R. (eds) The Ostracoda: Applications in Quaternary Research. American Geophysical Union, Geophysical Monograph, 131, 5-36.

Horne, D.J., Bunbury, J. \& Whittaker, J.E. 2011. Taxonomic harmonisation and calibration of nonmarine ostracods for palaeoclimate applications: the case of Candona acutula Delorme, 1967. Joannea Geologie und Paläontologie, 11, 76-79.

Horne, D.J., Martens, K., Schön, I. \& Smith, A.J. 2015. Taxonomic harmonisation of merged regional datasets of non-marine ostracods: a heuristic approach and its implications for palaeoenvironmental reconstruction. 8th European Ostracodologists' Meeting, University of Tartu, Estonia, Abstracts, 32.

Ikeya, N. \& Shimura, K. 1995. Ecology and adaption of the genus Spinileberis in the North Pacific. In: Riha, J. (ed.) Ostracoda and Biostratigraphy. Balkema, Rotterdam, 389-397.

Jain, S. 2008. Integrated Jurassic biostratigraphy: A closer look at nannofossil and ammonite evidences from the Indian subcontinent. Current Science, 95 , $326-331$.

Jones, T.R. 1849. A monograph of the Entomostraca of the Cretaceous Formation of England. Annual Volumes (Monographs) of the Palaeotographical Society, $3,1-40$.

Jones, T.R. 1884. Notes on the Foraminifera and Ostracoda from the deep boring at Richmond. Quarterly Journal of the Geological Society, 11, 765-777, http://doi.org/10.1144/GSL.JGS.1884.40.01-04.58

Jones, T.R. 1888. Ostracoda from the Weald Clay of the Isle of Wight. Geological Magazine, 3/3, 534-539.

Jones, T.R. \& Sherborn, C.D. 1888. On some Ostracoda from Fullers-earth Oolite and Bradford Clay. Proceedings of the Bath Natural History and Field Club, $\mathbf{6}$ $249-278$

Kaufmann, A. 1900. Cypriden und Darwinuliden der Schweiz. Revue Suisse de Zoologie, 8, 209-423.

Kilenyi, T. 1978. The Jurassic part III - Callovian-Portlandian. In: Bate, R.H. \& Robinson, E. (eds) A Stratigraphical index of British Ostracoda. Geological Journal Special Issue, 8, 256-298.

Klie, W. 1935. Voyage de Ch. Alluaud et P.A. Chappuis en Afrique Occidentale Française (Dec. 1930-Avril 1931): VIII. Ostracoda aus dem tropíschen Westafrika. Archiv für Hydrobiologie, 28, 35-68.

Klie, W. 1938. Die Tierwelt Deutschlands und der angrenzenden Meeresteile. 34: Krebstiere oder Crustacea. III: Ostracoda, Muschelkrebse. Gustav Fischer Verlag, Jena.

Kozur, H. 1972. Die Bedeutung triassischer Ostracoden für stratigraphische und paläoökologische Untersuchungen. Mitteilungen der Gesellschaft der Geologie und Bergbaustudenten in Oesterreich, 21, 623-660.

Latreille, P.A. 1806. Genera crustaceorum et insectorum, secundum ordinem naturalem et familias disposita. Amand Koenig, Paris, xviii, 1-302.

Leinfelder, R.R., Erbenich, A. \& Ramalho, M.M. 1988. Age and general facies development of the Ota Limestone (Estremadura, Portugal). Proceedings 2nd International Symposium on Jurassic Stratigraphy, Sept. 1987, Lisboa. Univerdidade Nova Lisboa Press, Lisboa, 2, 917-932.

Ljubimova, P.S. 1955. Ostrakody Mezozoyskikh otlozheniy srednego Povolzhya i Obshchego Syrta. Trudy Vsesoyuznogo Neftyango NauchnoIssledovatelskogo Geologo-razvedochnogo Instituta (VNIGRI), Novaya Seriya, 84, 3-189.

Lord, A.R. 1972. The ostracod genera Ogmoconcha and Procytheridea in the Lower Jurassic. Bulletin of the Geological Society of Denmark, 21, 319-336.

Malz, H. 1962. Palaeocytheridea im oberen Dogger NW-Deutschlands (Ostracoda). Senckenbergiana lethaea, 43, 235-241.

Mandelstam, M.I. 1947. Ostracoda iz otlozheniy sredney Yury poluostrova Mangyshlaka. Mikrofauna Neftyanykh Mestorozhdeniy Kavkaza, emby $i$ sredney Azii, 239-259. VNIGRI, Moskva/Leningrad.

Mandelstam, M.I. 1959. Ostrakody iz otlozheniy Paleogena sredney Azii. Trudy Vsesoyuznogo Neftyango Nauchno-Issledovatelskogo Geologo-razvedochnogo Instituta (VNIGRI), Novaya Seriya, 136 (Mikrofauna SSSR: 10), 442-542.

Maync, W. 1966. Microbiostratigraphy of the Jurassic of Israel. Geological Survey of Israel Bulletin, 40, ii +1-ii 56.

Mette, W. 1995. Ostracods from the Middle Jurassic of southern Tunisia Beringeria, 16, 259-348.

Mette, W. 1997. Palaeoecology and palaeobiogeography of the Middle Jurassic ostracods of southern Tunisia. Palaeogeography, Palaeoclimatology, Palaeoecology, 131, 65-111.

Mette, W. \& Geiger, M. 2004. Taxonomy and palaeoenvironments of Callovian Ostracoda from the Morondava Basin (south-west Madagascar). Beringeria, 34, 57-87

Mouterde, R., Rocha, R.B., Ruget, C. \& Tintant, H. 1979. Faciès, biostratigraphie et paléogéographie du Jurassique portugais. Ciências da Terra, 5, 29-52. 
Neil, J.V. 2000. Factors influencing intraspecific variation and polymorphism in marine podocopid Ostracoda, with particular reference to Tertiary species from southeastern Australia. Hydrobiologia, 419, 161-180.

Oertli, H.J. 1959. Malm-Ostrakoden aus dem schweizerischen Juragebirge. Denkschriften der Schweizerischen Naturforschenden Gesellschaft, 83, vi $+1-v i 44$

Olempska, E. \& Błaszyk, J. 2001. A boreal ostracod assemblage from the Callovian of Łuków area, Poland. Acta Palaeontologica Polonica, 46, 553-582.

Oppel, A. \& Waagen, W. 1866. Über die Zone des Ammonites transversarius. Benecke's geognostisch-palaöntologisch Beiträge, 1, 205-318. München.

Peterson, J.A. 1954. Jurassic Ostracoda from the 'Lower Sundance' and Rierdon Formations, western interior United States. Journal of Paleontology, 28, $153-176$.

Ramalho, M.M. 1970. Cylindroporella lusitanica, une nouvelle Dasycladacée du Jurassique supérieur portugais. Boletim da Sociedade Geológica de Portugal, 17, 123-127.

Ramalho, M.M. 1971. Contribution à l'étude micropaléontologique et stratigraphique du Jurassique supérieur et du Crétacé inférieur des environs de Lisbonne (Portugal). Memórias dos Serviços Geológicos de Portugal, 19, $1-212$.

Ramalho, M.M. 1981. Note préliminaire sur les microfaciès du Jurassique supérieur portugais. Comunicações dos Serviços Geológicos de Portugal, 67, $41-45$.

Roemer, F.A. 1841. Die versteinerungen des Norddeutschen Kreidegebirges. Hahn'schen Hofbuchhandlung Verlag, Hannover.

Rosenfeld, A. \& Honigstein, A. 1991. Callovian-Oxfordian ostracodes from the Hamakhtesh Hagadol section, southern Israel. Revista Española de Micropaleontologia, 23, 133-148.

Rosenfeld, A., Oertli, H.J., Honigstein, A. \& Gerry, E. 1987a. Oxfordian ostracodes from the Kidod Formation of the Majdal Shams area, Mount Hermon, Golan Heights. Bulletin des Centres de Recherche ExplorationProduction Elf-Aquitaine, 11, 233-248.

Rosenfeld, A., Gerry, E. \& Honigstein, A. 1987b. Jurassic ostracodes from Gebel Maghara, Sinai, Egypt. Revista Española Micropaleontología, 19, 251-280.

Rossetti, G. \& Martens, K. 1998. Taxonomic revision of the Recent and Holocene representatives of the Family Darwinulidae (Crustacea, Ostracoda), with a description of three new genera. Bulletin de l'Institut Royal des Sciences Naturelles de Belgique, Biologie, 68, 55-110.

Ruget-Perrot, C. 1961. Études stratigraphiques sur le Dogger et le Malm inférieur du Portugal au Nord du Tage. Memórias dos Serviços Geológicos de Portugal, 7, 1-197.

Sars, G.O. 1866. Oversigt af Norges marine ostracoder. Forhandlinger $i$ Videnskabs-selskebet $i$ Christiania, 1865, 1-130.

Sars, G.O. 1925. An account of the Crustacea of Norway with short descriptions and figures of all the species. Volume 9, parts 5-12. Bergen Museum, Bergen.

Sars, G.O. 1926. An account of the Crustacea of Norway with short descriptions and figures of all the species. Volume 9, parts 13-14. Bergen Museum, Bergen.

Schornikov, E.I. 1990. Evolution and classification of Bythocytheridae. Courier Forschungs-Institut Senckenberg, 123, 291-302.

Schudack, M.E. 2000. Ostracodes and charophytes from the Guimarota beds. In: Martin, T. \& Krebs, B. (eds) Guimarota - a Jurassic Ecosystem. Verlag Dr. Friedrich Pfeil, München, 33-36.

Schudack, U. 1997. Palaeocytheridea groissi n. sp. (Ostracoda) aus den Mörnsheimer Schichten (Tithonium) von Oberhartheim bei Vohburg (Donau). Geologische Blätter NO-Bayern, 47, 17-24.

Schudack, U. \& Schudack, M.E. 2000. Ostracods from the Upper Jurassic (Oxfordian-Tithonian) of southern Germany. Journal of Micropalaeontology, 19, 97-112, http://doi.org/10.1144/jm.19.2.97.

Sheppard, L.M. 1981. Bathonian ostracod correlation north and south of the English Channel with the description of two new Bathonian ostracods. In: Neale, J.W. \& Brasier, M.D. (eds) Microfossils from Recent and Fossil Shelf
Seas. Ellis Horwood, Chichester, for The British Micropalaeontological Society, 73-89.

Sherrington, P.F. \& Lord, A.R. 1975a. On Procytheridea exempla Peterson. A Stereo-Atlas of Ostracod Shells, 2, 247-254.

Sherrington, P.F. \& Lord, A.R. 1975b. On Procytheridea fraudator Sherrington \& Lord sp. nov.. A Stereo-Atlas of Ostracod Shells, 2, 255-262.

Silva, R.L., Mendonça Filho, J.G., Azerêdo, A.C. \& Duarte, L.V. 2014. Palynofacies and TOC analysis of marine and non-marine sediments across the Middle-Upper Jurassic boundary in the central-northern Lusitanian Basin (Portugal). Facies, 60, 255-276.

Sohn, I.G. 1982. Dryelbidae n. fam. from Continental Upper Jurassic and Lower Cretaceous rocks. In: Bate, R.H., Robinson, E. \& Sheppard, L.M. (eds) Fossil and Recent Ostracods. Ellis Horwood, Chichester, for The British Micropalaeontological Society, 305-325.

Stephenson, M.B. 1946. Weches Eocene Ostracoda from Smithville, Texas Journal of Paleontology, 20, 297-344.

Sylvester-Bradley, P.C. 1948. Bathonian Ostracods from the Boueti Bed of Langton Herring, Dorset. Geological Magazine, 85, 185-204.

Sylvester-Bradley, P.C. 1973. On Theriosynoecum wyomingense (Branson). A Stereo-Atlas of Ostracod Shells, 1, 205-212.

Tesakova, E. 2013a. Ostracods of the Genus Palaeocytheridea Mandelstam in the Middle and Upper Jurassic of Europe: 1. Development of ideas on the content of the genus and the results of its revision. Paleontological Journal, 47, 256-271.

Tesakova, E. 2013b. Ostracods of the Genus Palaeocytheridea Mandelstam in the Middle and Upper Jurassic of Europe: 2. Description of taxa. Paleontological Journal, 47, 485-494.

Tesakova, E. 2013c. Ostracoda, genus Palaeocytheridea Mandelstam, 1947 from the Middle and Upper Jurassic of Europe: revision, stratigraphy, paleobiogeography. Il Naturalista Siciliano, 37, 395-398.

Tesakova, E. 2014. Ostracods of the Genus Palaeocytheridea Mandelstam in the Middle and Upper Jurassic of Europe: 3. Stratigraphy and paleobiogeography. Paleontological Journal, 48, 53-57.

Triebel, E. 1951. Einige stratigraphische wertvolle ostracoden aus dem höheren Dogger Deutschlands. Abhandlungen der Senckenbergischen Naturforschenden Gesellschaft, 485, 87-102.

Triebel, E. \& Bartenstein, H. 1938. Die Ostracoden des deutschen Juras. I. Monoceratina-Arten aus dem Lias und Dogger. Senckenbergiana, 20, 502-518.

Wakefield, M.I. 1994. Middle Jurassic (Bathonian) Ostracoda from the Inner Hebrides, Scotland. Palaeontographical Society, London, Monographs, 148.

Wakefield, M.I. 2009. Bathonian of the Inner Hebrides, Scotland. In: Whittaker, J.E. \& Hart, M.B. (eds) Ostracods in British Stratigraphy. The Micropalaeontological Society, Special Publications, 225-240.

Weaver, P.P.E. 1982. Ostracoda from the British Lower Chalk and Plenus Marls Palaeontographical Society, London, Monographs, 1982.

Whatley, R.C. 1970. Scottish Callovian and Oxfordian Ostracoda. Bulletin of the British Museum (Natural History), Geology, 19, 297-358.

Whatley, R.C. \& Ballent, S. 1996. A review of the Mesozoic ostracod genus Progonocythere and its close allies. Palaeontology, 39, 919-939.

Whatley, R.C. \& Ballent, S. 2004. A review of the Mesozoic ostracod genus Lophocythere and its close allies. Palaeontology, 47, 81-108.

Wienholz, E. 1967. Neue Ostracoden aus dem norddeutschen Callov. Freiberger Forschungshefte, C213, 23-51.

Wilkinson, I.P. \& Whatley, R.C. 2009. Upper Jurassic (Callovian-Portlandian) In: Whittaker, J.E. \& Hart, M.B. (eds) Ostracods in British Stratigraphy. The Micropalaeontological Society, Special Publications, 241-287.

Wilson, R.C.L., Hiscott, R.N., Willis, M.G. \& Gradstein, F.M. 1989. The Lusitanian Basin of West-Central Portugal: Mesozoic and Tertiary tectonic, stratigraphic and subsidence history. American Association of Petroleum Geologists Memoir, 46, 341-362. 